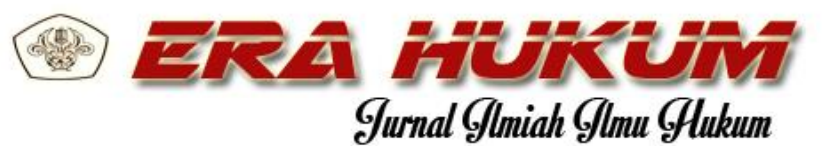

Volume 16, Nomor 1, Juni 2018

ISSN 0854-8242 | e-ISSN 2581-0359

Fakultas Hukum - Universitas Tarumanagara Open Access at: wwwjournal.untar.ac.id/index.php/hukum

Era Hukum - Jurnal Imiah Ilmu Hukum is licensed under Creative Commons Attrib ution 4.0 International License, which allows other writers to use, distribute, and/or build upon this article, as long as the original work is properiy cited.

\title{
EFEKTIVITAS SANKSI DEWAN KEAMANAN PERSERIKATAN BANGSA-BANGSA TERHADAP KONFLIK BERSENJATA DI SURIAH
}

Teddy Nurcahyawan

(Dosen tetap Hukum Internasional, Fakultas Hukum Universitas Tarumanagara)

(E-mail: teddyn@fh.untar.ac.id)

Lauw Wisnu

(Mahasiswa Hukum Internasional, Fakultas Hukum Universitas Tarumanagara)

Received: 28 Maret 2018; Accepted: 22 Agustus 2018; Published: 19 September 2018

\begin{abstract}
As a soverign state in the Middle East, Syria has received badly effect of Arab Spring revolution. Thousand of students launched demonstration claiming Bashar Al-Assad to step down. In response to it, Bashar Al-Assad attacked the prodemocracy students by arresting and torturing them. This arms conflict has not only brought many civilians as victims of civil war but involved some other foreign states as well. To avoid matters worse, Security Council of United Nations has issued a Resolution Number 2328/2016 to give sanctions affirming Bashar-Assad to have violated international humanitarian law. The question comes up whether or not this resolution could present the effectiveness of the sanctions. This research has revealed that the Security Council Resolution is effective and Syria has complied with it in line with the international law.
\end{abstract}

Keywords: Effectiveness, sanction, UN Security Council

\section{Pendahuluan}

\section{A. Latar Belakang Masalah}

Konflik di Suriah telah berlangsung selama 6 tahun sejak tahun 2011 sampai sekarang ${ }^{1)}$ dan merupakan dampak dari revolusi sporadik pada

1) https://www.icrc.org/en, diakses pada tanggal 3 Januari 2017, Pukul 19:22 WIB.

2) Apriadi Tamburaka, Revolusi Timur Tengah, negara-negara di Timur Tengah, konflik bersenjata ini dimulai dari Tunisia dan kemudian menyebar ke Mesir, sampai ke Suriah serta dikenal dengan istilah Musim Semi Arab atau Arab Spring. ${ }^{2)}$ Konflik di Suriah berawal di sebuah

Kejatuhan Para Penguasa Otoriter di NegaraNegara Timur Tengah, Narasi, Jakarta, 2011, hal. 9. 


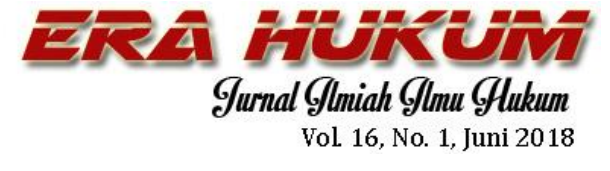

kota kecil yang disebut Deraa dan kemudian pecah di Damaskus. ${ }^{3)}$ Konflik bersenjata di Suriah berawal dari adanya aksi unjuk rasa yang dilakukan oleh kelompok pro-demokrasi yang menentang pihak penguasa Suriah pada tanggal 15 Maret 2011 di bagian selatan kota Deraa setelah adanya penangkapan dan penyiksaan terhadap beberapa remaja yang menggambar sloganslogan revolusi di dinding sekolah. ${ }^{4)} 15$ orang remaja, yang semuanya masih berusia di bawah 17 tahun, ditangkap dan disiksa setelah diketahui menggambar slogan di dinding-dinding sekolah yang menjadi ciri khas dari Arab Spring: "The people want the fall of the regine". 5 )

Di Suriah dilakukan penyerangan besar-besaran oleh pihak penguasa terhadap warga negara Suriah yang

3) Trias Kuncahyono, Musim Semi di Suriah, Anak-Anak Sekolah Penyulut Revolusi, Kompas, Jakarta, 2013, hal. 9.

4) http://www.bbc.com/news/world-middle-east26116868, Diakses pada tanggal 23 April 2017, pukul 14:30 WIB.

5) Frederick C. Hoff and Alex Simon, Sectarian Violence in Syria's Civil War: Causes, Consequences, and Recommendations and mitigations, Edisi Maret 2013, The Center for the Prevention of Genocide: United States Holocaust Memorial Museum, 2013, hal. 1.
Teddy Nurcahyawan \& Lauw Wisnu Efektivitas Sanksi Dewan Keamanan Perserikatan Bangsa-bangsa...

mayoritasnya aliran Sunni, populasinya sangat dominan di Suriah, mereka melakukan pemberontakan untuk mewujudkan revolusi sebagai tujuan mereka yaitu melengserkan pemimpin mereka yang dipimpin oleh Bashar AlAssad. Konflik di Suriah telah menelan korban sebanyak ribuan jiwa dan membuat ribuan warga Suriah mengungsi ke negara lain untuk menyelamatkan diri. ${ }^{6}$ Tindakan Bashar Al-Assad telah menjadi pelanggaran atas hak asasi manusia ${ }^{7)}$ yang seharusnya dilindungi oleh masyarakat internasional dan PBB (Perserikatan Bangsa-Bangsa).

Konflik di Suriah terus berjalan dan melibatkan banyak pihak sehingga membentuk banyak kelompok yang dapat dibagi menjadi tiga kelompok besar, yakni:8)

6) Alfian Maulana, "Konflik Suriah", Makalah (Jakarta: Universitas Muhammadiyah, 2012), hal. 3 .

http://www.un.org/press/en/2011/sc10403.doc. htm, Diakses pada tanggal 21 Mei 2017, Pukul 14:29WIB.

8) Christopher M. Blanchard, Carla E. Humud dan Mary Beth D. Nikitin, Armed Conflict in Syria: Overview and U.S. Response, Congressional Research Service, edisi 9 


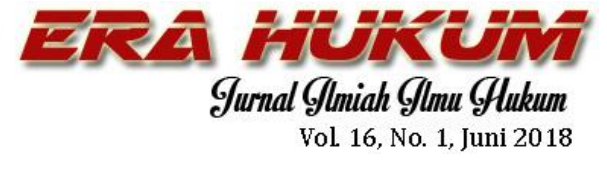

1. Kelompok pro-pemerintah:

a. Syrian Armed Forces and National Defense Forces

b. Lebanese Hezbollah

c. Iraqi and Other Shia Militias

2. Kelompok anti pemerintah:

a. Southern Front Forces

b. Nusra Front (Jabhat al Nusra, The Support Front for the People of Syria)

c. The Islamic State (aka ISIL/ISIS/Daesh)

3. Kelompok Kurdi dan oposisi politik:

a. Kurdish Democratic Unity Party (Partiya Yekitiya Demokrat, PYD)

b. Popular Protection Units (Yekineyen ParastinaGel, YPG)

Konflik di Suriah belum menemukan titik terangnya hingga saat ini dan bahkan diperparah dengan adanya intervensi-intervensi dari negara-negara lain yang memberikan respon terhadap konflik yang terjadi di Suriah dengan prioritas dan pandangan mereka masing-masing. Salah satu upaya untuk memberikan pertolongan terhadap warga sipil Suriah yang menjadi korban dari konflik bersenjata

Oktober 2015, Congressional Research Service, 2015, hal. 10 .

9)

https://www.un.org/en/ga/search/view_doc.asp
Teddy Nurcahyawan \& Lauw Wisnu Efektivitas Sanksi Dewan Keamanan Perserikatan Bangsa-bangsa...

ini Dewan Keamanan (DK) PBB mengeluarkan Resolusi Dewan Keamanan PBB Nomor 2328 dengan judul The Situation in The Middle East (Syria). Isi dari salah satu poin di dalam resolusi tersebut sebagai berikut:

"Demands that all parties allow complete, immediate, unconditional, safe and unhindered access for the United Nations and its implementing partners, in order to ensure that humanitarian assistance reaches people through the most direct route in order to meet basic needs, including the provision of medical care, consistent with the provisions of its resolution 2258 (2015) for the whole of Syria and respect and protect all civilians across Aleppo and throughout Syria; stresses that all parties must respect their obligations under international humanitarian law and, in particular, to respect and protect civilians and civilian objects,"9)

Inti poin di atas adalah untuk meminta semua pihak untuk memberikan bantuan bagi korban di Suriah seperti penyediaan bantuan medis dan melindungi seluruh

?symbol=S/RES/2328(2016), diakses pada tanggal 27 April 2017, Pukul 17:05 WIB. 


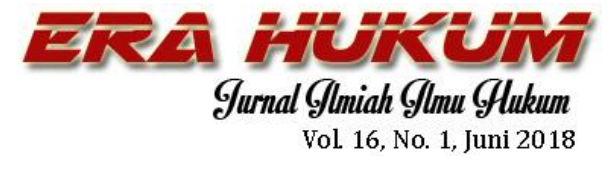

penduduk sipil dan obyek sipil di Suriah. Dikeluarkannya resolusi di atas merupakan wujud dari kewenangan Dewan Keamanan PBB sebagaimana yang tercantum dalam Pasal 24 ayat (1) dan (2) Piagam PBB yang menyatakan:

1. Untuk menjamin agar Perserikatan Bangsa-Bangsa dapat menjalankan tindakannya dengan lancar dan tepat, maka Anggotaanggota memberikan tanggung jawab utama kepada Dewan Keamanan untuk memelihara perdamaian dan keamanan internasional, dan menyetujui agar supaya Dewan Keamanan dalam menjalankan kewajibankewajiban bagi pertanggungjawaban ini bertindak atas nama mereka.

2. Dalam menjalankan kewajibankewajiban ini Dewan Keamanan akan bertindak sesuai dengan Tujuan-tujuan dan Prinsip-prinsip Perserikatan Bangsa-Bangsa. Kekuasaan khusus yang diberikan kepada Dewan Keamanan untuk menjalankan kewajibankewajiban ini tercantum dalam Bab VI, VII, VIII dan XII.

Pasal 24 ayat (1) dan (2) di atas berkaitan dengan pasal 41 dan 42 Piagam PBB. Pasal 41 menjelaskan bahwa:

"Dewan Keamanan dapat
memutuskan tindakan-tindakan apa
di luar penggunaan kekuatan
Teddy Nurcahyawan \& Lauw Wisnu Efektivitas Sanksi Dewan Keamanan Perserikatan Bangsa-bangsa...

senjata harus dilaksanakan agar keputusan-keputusannya dapat dijalankan, dan dapat diminta kepada Anggota-anggota Perserikatan Bangsa-Bangsa untuk melaksanakan tindakan-tindakan itu. Termasuk tindakan-tindakan itu ialah pemutusan seluruhnya atau sebagian hubungan-hubungan ekonomi, termasuk hubungan kereta api, laut, udara, pos, telegraf, radio dan alat-alat komunikasi lainnya, serta pemutusan hubungan diplomatik."

Kemudian Pasal 42 menjelaskan bahwa:

"Apabila Dewan Keamanan menganggap bahwa tindakantindakan yang telah ditentukan dalam pasal 41 tidak mencukupi atau telah terbukti tidak mencukupi, maka Dewan dapat mengambil tindakan dengan mempergunakan angkatan udara, laut atau darat yang mungkin diperlukan untuk memelihara atau memulihkan perdamaian serta keamanan internasional. Dalam tindakan itu termasuk pula demonstrasidemonstrasi, blokade, dan tindakantindakan lain dengan mempergunakan angkatan udara, laut, atau darat dari anggotaanggota Perserikatan BangsaBangsa."

Syarat untuk dikeluarkannya sebuah Resolusi Dewan Keamanan PBB tercantum di dalam pasal 27 


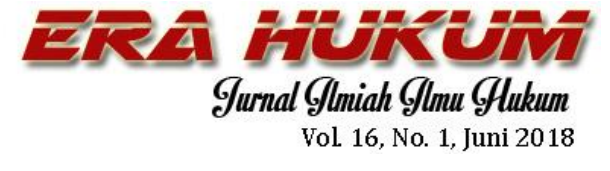

Piagam PBB yang menyatakan sebagai berikut:

1. Setiap Anggota Dewan Keamanan berhak memberikan satu suara.

2. Keputusan-keputusan Dewan Keamanan mengenai hal-hal prosedural ditetapkan berdasarkan suara setuju dari sembilan anggota.

3. Keputusan-keputusan Dewan Keamanan mengenai hal-hal lain ditetapkan dengan suara setuju dari sembilan anggota termasuk suara anggota-anggota tetap; dengan ketentuan bahwa, dalam keputusan keputusan di bawah yang diambil dalam rangka $\underline{\mathrm{Bab}}$ VI, dan ayat 3 Pasal 52, pihak yang berselisih tidak ikut memberikan suara.

Menurut ketentuan Pasal 52 Piagam PBB, negara yang bersengketa tidak diperkenankan memberikan suara. Alasan sah bagi pemberian status luar biasa bagi kelima anggota tetap Dewan Keamanan PBB terletak dalam "inescapable fact of power differential". Dengan kata lain, dasar pemikiran yang melandasinya yaitu negara-negara inilah yang dibebankan tanggung jawab terberat untuk

${ }^{10)}$ James Barros, The League of Nations and The Great Powers, The Greek, Bulgarian Incident, 1970, hal.8.
Teddy Nurcahyawan \& Lauw Wisnu Efektivitas Sanksi Dewan Keamanan Perserikatan Bangsa-bangsa...

memelihara perdamaian dan keamanan internasional dan oleh karena itu mereka diberikan hak suara final dan menentukan dalam memutuskan bagaimana tanggung jawab itu harus dilaksanakan. ${ }^{10)}$ Hal ini seperti terdapat pada Resolusi Dewan Keamanan PBB Nomor 2328 tahun 2016, tidak ada anggota tetap Dewan Keamanan PBB yang melakukan veto terhadap resolusi tersebut. Alasan dalam konflik di Suriah ini, Resolusi Nomor 2328 Dewan Keamanan PBB mendapatkan suara bulat dan tidak diveto oleh anggota tetap Dewan Keamanan PBB. ${ }^{11}$

Penulis membatasi ruang lingkup penelitian ini pada perkembangannya hingga akhir tahun 2016 saja dikarenakan adanya kemungkinan terjadinya perubahan-perubahan yang fundamental dalam perkembangan konflik bersenjata di Suriah.

\section{B. Permasalahan}

Berdasarkan latar belakang yang

\footnotetext{
11) http://syriainstitute.org/calendar/unscadopts-resolutions-2328-2016-regardingmonitorin g-of-aleppo-evacuation/, Diakses pada tanggal 19 April 2017.
} 


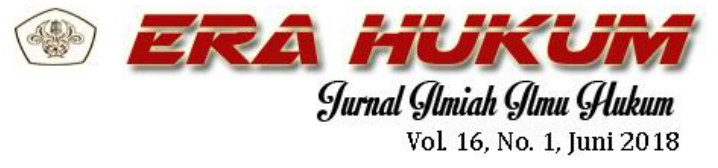

telah diuraikan di atas, penulis merumuskan masalah penelitian ini menjadi bagaimanakah efektivitas pelaksanaan Resolusi Dewan Keamanan Perserikatan Bangsa-Bangsa Nomor 2328 Tahun 2016 terhadap konflik bersenjata di Suriah?

\section{Metode Penelitian}

Metode pengumpulan data dilakukan dengan studi kepustakaan dan wawancara untuk mendapatkan validitas atau kebenaran dari data yang didapatkan serta menghimpun informasi yang relevan dengan topik atau masalah yang akan atau sedang diteliti. ${ }^{12)}$ Sedangkan wawancara adalah proses tanya jawab yang dilakukan secara lisan

12)

https://www.scribd.com/doc/57297015/Pengert ian-studi-kepustakaan, diakses pada tanggal 29 Januari 2017.

${ }^{13)}$ http://www.pengertianpakar.com/2015/06/pe ngertian-wawancara-dan-jenis-jeniswawancara.html, diakses pada tanggal 29 Januari 2017.

14) Indonesia, Piagam Perserikatan BangsaBangsa, Pasal 23:

1. Dewan Keamanan terdiri dari lima-belas Anggota Perserikatan Bangsa-Bangsa. Republik Cina, Perancis, Uni Republik Sosialis Soviet, Kerajaan Inggris dan lrlandia Utara, dan Amerika Serikat merupakan anggota-anggota tetap Dewan Keamanan. Majelis Umum memilih sepuluh
Teddy Nurcahyawan \& Lauw Wisnu Efektivitas Sanksi Dewan Keamanan Perserikatan Bangsa-bangsa...

antara dua orang atau lebih yang terdiri dari pewawancara (interviewer) dan pihak yang diwawancarai (interviewee) dengan tujuan mendapatkan informasi yang sahih bagi pewawancara. ${ }^{13)}$ Wawancara biasanya ditujukan kepada pihak-pihak yang memiliki keahlian di dalam bidang tertentu sesuai dengan informasi yang dibutuhkan oleh pewawancara.

\section{PEMBAHASAN}

\section{A. Tinjauan Umum Mengenai}

Dewan Keamanan Perserikatan

Bangsa-Bangsa (PBB)

Pasal 23 Piagam $\mathrm{PBB}^{14)}$, yang telah diubah, menyatakan bahwa Dewan

Anggota Perserikatan Bangsa-Bangsa lainnya sebagai anggota tidak tetap Dewan Keamanan, dengan memberikan perhatian utama kepada Anggotaanggota Perserikatan Bangsa-Bangsa yang memberikan sumbangan untuk pemeliharaan perdamaian dan keamanan international dan untuk keperluan-keperluan lainnya bagi Organisasi serta kepada asas pembagian geografis yang adil.

2. Anggota-anggota tidak tetap Dewan Keamanan dipilih untuk jangka waktu dna tahun. Pada pemilihan anggota-anggota tidak tetap yang pertama setelah penambahan anggota Dewan Keamanan dari sebelas menjadi lima betas, dua dari empat anggota tambahan dipilih untuk jangka 


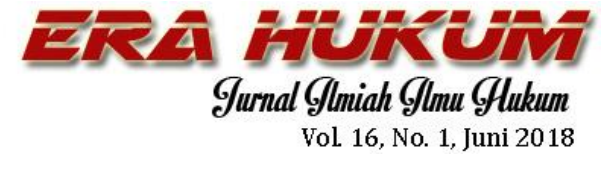

Keamanan terdiri atas 15 anggota, 5 di antaranya merupakan anggota-anggota tetap yaitu China, Perancis, Rusia, Inggris, dan Amerika Serikat. Kelima anggota ini menikmati status luar biasa (eksepsional) tidak hanya berdasarkan status permanennya saja tetapi juga oleh alasan-alasan hak suara khusus antara lain, seperti kekuasaan “veto"15). Veto merupakan hak istimewa yang dimiliki oleh 5 negara besar anggota tetap Dewan Keamanan PBB, yang lazim disebut "the big five". Kelima negara tersebut adalah AS, Inggris, Perancis, China dan Rusia (sebagai pengganti Uni Soviet). Hak istimewa tersebut adalah hak untuk menolak atau membatalkan suatu keputusan Dewan Keamanan PBB. ${ }^{16)}$ Walaupun istilah veto ini sendiri tidak terdapat dalam Piagam PBB, tetapi kelima anggota tetap DK PBB memiliki apa yang dinamakan "veto". 17 Jadi apabila salah satu negara anggota tetap DK PBB menggunakan hak

waktu satu tahun. Anggota yang telah selesai masa keanggotaannya tidak dapat segera dipilih kembali.

3. Setiap anggota Dewan Keamanan hanya diwakili oleh satu utusan saja.

15) Ibid.
Teddy Nurcahyawan \& Lauw Wisnu Efektivitas Sanksi Dewan Keamanan Perserikatan Bangsa-bangsa...

vetonya untuk menolak suatu keputusan yang telah disepakati anggota yang lain, maka keputusan tersebut tidak dapat dilaksanakan. ${ }^{18)}$

Alasan sah bagi pemberian status luar biasa kepada kelima anggota tetap ini didasari oleh "inescapable fact of powers differentials" yang didasari oleh pemikiran bahwa kelima negara inilah yang mengemban tanggung jawab terberat untuk memelihara perdamaian dan keamanan internasional dan oleh karena itu kepada mereka harus diberikan hak suara final dan menentukan dalam memutuskan tentang bagaimana tanggung jawab itu harus dilaksanakan. ${ }^{19)}$

Kesepuluh anggota Dewan Keamanan lainnya yaitu anggotaanggota tidak tetap, dipilih untuk menjabat selama dua tahun melalui Majelis Umum, dan tidak dapat secepatnya dipilih kembali pada pemilihan periode berikutnya. ${ }^{20)}$ Setiap

\footnotetext{
16) Soeprapto, Hubungan Internasional, Sistem, Interaksi dan Perilaku, Raja Grafindo Persada, Jakarta, 1995, hal. 387.

17) Ibid.

18) Ibid.

19) Ibid, hal. 35 .

20) Ibid.
} 


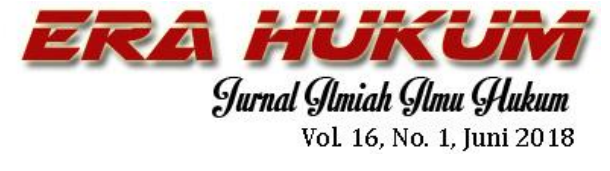

tahun dipilih lima anggota dengan mayoritas suara $2 / 3$ suara mayoritas pemilih.

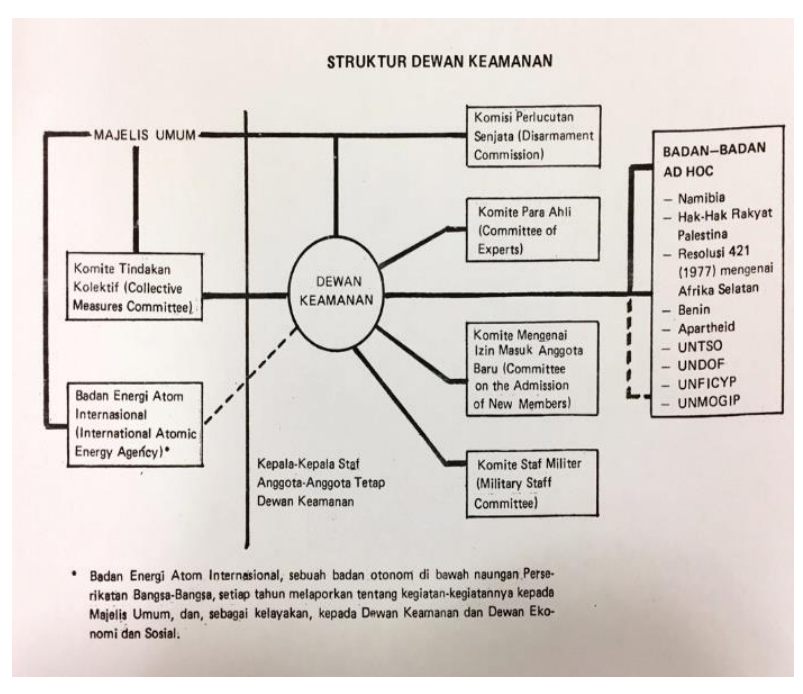

\section{B. Peran Utama Dewan Keamanan Perserikatan Bangsa-Bangsa (PBB)}

Peran utama Dewan Keamanan dikukuhkan dalam Pasal 24 ayat (1) Piagam PBB yang menyatakan:

"Agar PBB dapat mengambil tindakan segera dan efektif, negaranegara anggota memberikan tanggung jawab utama kepada Dewan Keamanan untuk

21) James Barros, United Nation, Past,Present and Future, diterjemahkan oleh D.H.Gulo, PBB, Dulu,kini dan Esok, Edisi Pertama, Bumi Askara, Jakarta, 1984, hal. 7.

${ }^{22)} \mathrm{F}$. Sugeng Istanto, Op.Cit, hal.178.
Teddy Nurcahyawan \& Lauw Wisnu Efektivitas Sanksi Dewan Keamanan Perserikatan Bangsa-bangsa...

pemeliharaan perdamaian dan keamanan internasional dan setuju bahwa Dewan Keamanan dalam melaksanakan tugasnya bertindak atas nama negara-negara anggota."

Pasal 24 ayat (1) di atas memberikan tanggung jawab bagi Dewan Keamanan untuk memelihara perdamaian dan keamanan internasional ${ }^{21)}$ sesuai dengan salah satu tujuan dari PBB yang tercantum di dalam Pasal 1 ayat (1) Piagam PBB yaitu memelihara perdamaian dan keamanan internasional. ${ }^{22)}$

Agar perdamaian dan keamanan internasional dapat terpelihara tentu sengketa-sengketa antara negara anggota harus diselesaikan secara damai. $^{23)}$ Penyelesaian sengketasengketa internasional secara damai diatur dalam Bab VI Piagam PBB. Yang sangat menarik perhatian di sini ialah bahwa untuk mengajukan suatu sengketa ke Dewan Keamanan tidak diperlukan persetujuan pihak lain. ${ }^{24)}$ Jadi suatu negara dapat langsung meminta

\footnotetext{
23) Prof. Dr. Boer Mauna, Hukum Internasional, Pengertian Peranan dan Fungsi dalam Era Dinamika Global, Edisi kedua, Cetakan keenam, Alumni, Bandung, 2015, hal. 217. 24) Ibid.
} 


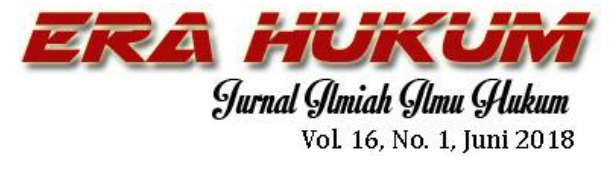

perhatian Dewan Keamanan dan dalam hal ini persoalan kedaulatan sudah dikesampingkan. ${ }^{25)}$

Selain peranan Dewan Keamanan PBB untuk menyelesaikan sengketa secara damai, terdapat juga tindakan pemaksaan yang dapat diambil oleh PBB terkait penyelesaian suatu sengketa antarnegara. Bab VII Piagam PBB mengatur tentang tindakantindakan yang berkaitan dengan ancaman-ancaman terhadap perdamaian, pelanggaran terhadap perdamaian, dan tindakan agresi. Berdasarkan Pasal 3926) Piagam PBB, Dewan Keamanan memiliki kewenangan untuk menentukan, atas nama organisasi secara keseluruhan, apakah ada suatu "ancaman perdamaian, pelanggaran-pelanggaran perdamaian, atau tindakan agresi" atau tidaknya dan keputusannya mengenai suatu tindakan pemaksaan yang diambil, setidak-tidaknya secara

25) Ibid.

26) Indonesia, Piagam Perserikatan BangsaBangsa, Pasal 39:

Dewan Keamanan akan menentukan ada tidaknya sesuatu ancaman terhadap perdamaian, pelanggaran terhadap perdamaian atau tindakan agresi dan akan menganjurkan atau
Teddy Nurcahyawan \& Lauw Wisnu Efektivitas Sanksi Dewan Keamanan Perserikatan Bangsa-bangsa...

teoritis, mengikat atas negara-negara anggota berdasarkan Pasal 25. ${ }^{27)}$

Dewan Keamanan memiliki dua jenis tindakan pemaksaan yang diberikan kepadanya; yaitu yang dimuat dalam Pasal 41, yakni, yang tidak melibatkan penggunaan kekuatan senjata, dan yang dimuat dalam Pasal 42, yakni yang melibatkan tindakan tindakan angkatan udara, laut atau angkatan darat. ${ }^{28)}$ Sebelum memutuskan hal itu perlu bagi Dewan untuk "menentukan adanya bahaya bagi suatu ancaman terhadap perdamaian, pelanggaran perdamaian, pelanggaran perdamaian dan tindakan agresi” berdasarkan Pasal 38. ${ }^{29}$

\section{Kekuatan Mengikat Resolusi Dewan Keamanan Perserikatan \\ Bangsa-Bangsa}

Sifat keputusan atau Resolusi sebagai perjanjian yang ditetapkan oleh

memutuskan tindakan apa yan harus diambil sesuai dengan pasal 41 dan 42, untuk memelihara atau memulihkan perdamaian dan keamanan internasional.

27) Ibid, hal. 46.

28) Ibid.

29) Ibid. 


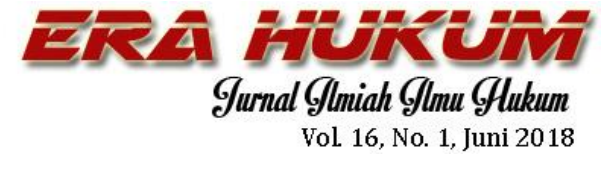

Dewan Keamanan PBB adalah sangat berbeda dari Resolusi yang dikeluarkan oleh badan utama lainnya seperti Majelis Umum PBB, Dewan Perwalian, dan Dewan ECOSOC. ${ }^{30)}$ Keputusankeputusan dari ketiga badan utama tersebut mempunyai dua sifat, yakni bersifat hanya mengikat secara internal dan rekomendatif. ${ }^{31)}$

Sedangkan keputusan Dewan Keamanan benar-benar mempunyai kekuatan hukum yang mengikat dan bahkan dapat bertentangan dengan prinsip hukum internasional, yang tidak hanya mengikat bagi negara-negara anggota $\mathrm{PBB}$, melainkan juga mengikat bagi negara-negara yang bukan merupakan anggota PBB. ${ }^{32)}$

Untuk menjamin agar PBB dapat menjalankan tugas dan wewenangnya secara lancar dan tepat maka anggota memberikan tanggung jawab utama (primary responsibility) kepada Dewan Keamanan PBB untuk memelihara

\footnotetext{
${ }^{30)}$ http://www.landasanteori.com/2015/10/resol usi-dewan-keamanan-pbb-prosedur.html, Diakses pada tanggal 26 April 2017, Pukul 22:10 WIB.

31) James Barros, Op.Cit, hal. 102.

${ }^{32)} \mathrm{http}$ ://www.landasanteori.com/2015/10/resol usi-dewan-keamanan-pbb-prosedur.html,
}

Teddy Nurcahyawan \& Lauw Wisnu Efektivitas Sanksi Dewan Keamanan Perserikatan Bangsa-bangsa...

perdamaian dan keamanan internasional, dan menyetujui agar Dewan Keamanan dalam menjalankan kewajibannya bertindak atas nama semua anggota $\mathrm{PBB},{ }^{33)}$ sehingga pada prinsipnya Dewan Keamanan tidak dapat bertindak sewenang-wenang.

Pada saat yang sama, anggotaanggota PBB terikat dengan tindakan yang dilakukan oleh Dewan Keamanan dan menurut Pasal 25 Piagam PBB, mereka setuju dan menerima dan melaksanakan keputusan-keputusan yang dikeluarkan Dewan Keamanan sesuai dengan piagam sehingga resolusi-resolusi yang dikeluarkan mempunyai daya hukum yang mengikat (legal binding). ${ }^{34)}$

Keputusan-keputusan Dewan Keamanan PBB mempunyai dampak bagi suatu negara yang terlibat konflik atau sengketa untuk mematuhi dan

Loc.Cit, Lihat Pasal 25, pasal 2 ayat (6) serta Pasal 49 Piagam PBB.

33) Ibid, Lihat Pasal 24 ayat (1) dan (2) Piagam PBB

34) Ibid. 


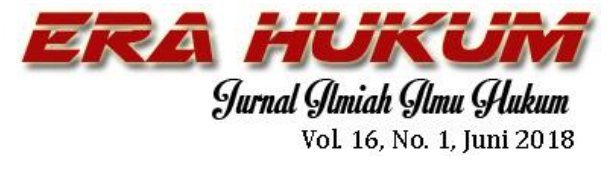

melaksanakan keputusannya tersebut. ${ }^{35)}$ Dalam hal ini, jika Dewan Keamanan melakukan tindakan-tindakan pencegahan atau pemaksaan terhadap suatu negara, negara lain baik negara yang merupakan anggota PBB maupun bukan anggota PBB yang menghadapi persoalan-persoalan ekonomi akibat tindakan yang dilakukan oleh Dewan Keamanan, berhak untuk menyelesaikan persoalan tersebut. ${ }^{36)}$

Dengan demikian suatu keputusan Dewan Keamanan memiliki kekuatan hukum mengikat baik bagi negara anggotanya maupun bukan anggotanya. ${ }^{37)}$ Jika dipandang berdasarkan prinsip hukum internasional, tentulah hal ini sangat bertentangan. ${ }^{38)}$ tetapi ketentuan tentang keputusan Dewan Keamanan PBB adalah mengikat secara hukum.

Hal ini telah dijamin sebagaimana telah ditetapkan dalam Pasal 2 ayat (6) Piagam PBB yang menyatakan bahwa

\footnotetext{
${ }^{35)}$ http://www.landasanteori.com/2015/10/resol usi-dewan-keamanan-pbb-prosedur.html, Loc.Cit. .

36) Ibid. Lihat Pasal 50 Piagam PBB.

37) Ibid.

38) Pasal 24 Konvensi Wina 1969 menyatakan bahwa suatu perjanjian internasional tidak
}

Teddy Nurcahyawan \& Lauw Wisnu Efektivitas Sanksi Dewan Keamanan Perserikatan Bangsa-bangsa...

negara-negara yang bukan negara anggota PBB bertindak sesuai dengan prinsip-prinsip apabila dianggap perlu untuk perdamaian dan keamanan internasional. Oleh karena itu negaranegara yang bukan anggota PBB terikat oleh keputusan Dewan Keamanan apabila keputusan tersebut bertujuan untuk perdamaian dan keamanan internasional, sehingga bagi negara yang melanggar keputusan-keputusan Dewan Keamanan akan dikenakan sanksi sebagaimana diatur dalam Piagam PBB. ${ }^{39)}$ Sanksi tersebut bisa berupa tindakan yang menggunakan kekerasan tanpa mempergunakan kekuatan militer (Pasal 41 Piagam PBB) dan tindakan yang menggunakan kekuatan militer. ${ }^{40}$

Prinsip non-intervensi memiliki prinsip tandingan yaitu prinsip Responsibility to Protect, yaitu prinsip yang menjelaskan bahwa:

melahirkan kewajiban bagi pihak ketiga (nec nocent nec prosunt).

39)

http://www.landasanteori.com/2015/10/resolusi -dewan-keamanan-pbb-prosedur.html, Loc.Cit. .

40) Sri Setianingsih Suwardi, Op.Cit. hal 137. 


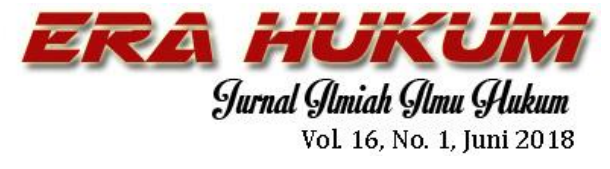

"The idea that the souvereign states have a responsibility to protect their own citizens from avoidable catastrophe-from mass murder and rape, from starvation- but when they are unwilling or unable to do so, that responsibiity must be borne by the broader community of states." ${ }^{41)}$

Hal ini menyatakan bahwa ketika suatu negara yang berdaulat tidak mau atau tidak mampu melindungi penduduknya dari bencana kemanusiaan seperti pembantaian massal dan pemerkosaan atau kelaparan maka tanggungjawab negara yang berdaulat tersebut berpindah ke tangan komunitas negara yang lebih luas. Bentuk dan dimensi pertanggungjawaban tersebut didiskusikan ke pertanyaan-pertanyaan seperti siapa yang harus bertanggungjawab, kapan, dimana, dan bagaimana tanggungjawab tersebut dilaksanakan. ${ }^{42)}$

Ketika tidak didapatkan suatu daftar tunggal mengenai hal itu (kriteria untuk melakukan intervensi militer

41) Füsun Türkmen, Cyprus 1974 Revisited: Was It Humanitarian Intervention? Perceptions, Galatasaray University, 2005, hal.63.
Teddy Nurcahyawan \& Lauw Wisnu Efektivitas Sanksi Dewan Keamanan Perserikatan Bangsa-bangsa...

untuk perlindungan terhadap kemanusiaan) dalam penilaian Komisi, maka disusunlah keputusan yang relevan mengenai "right authority, just cause, right intention, last resort, proportional means and reasonable prospects. ${ }^{43)}$ Dinyatakan sebagai berikut:

"The Security Council should be the first reference on any matter relating to military intervention for humanitarian purposes, but in case it fails to fulfill this role for any reason, the General Assembly, or regionals/sub-regional

organizations could undertake collective action. Following their failure to act, a military intervention might be undertaken by an ad hoc coalition or individual state, provided that it respects all the criteria hereafter." ${ }^{44)}$

Dewan Keamanan PBB diharuskan menjadi referensi utama dalam segala hal terkait dengan intervensi atas dasar kemanusiaan, namun apabila Dewan Keamanan PBB gagal untuk melaksanakan fungsinya, Majelis Umum atau organisasi regional maupun organisasi sub-regional harus

\footnotetext{
42) Ibid.

43) Ibid.

44) Ibid.
} 


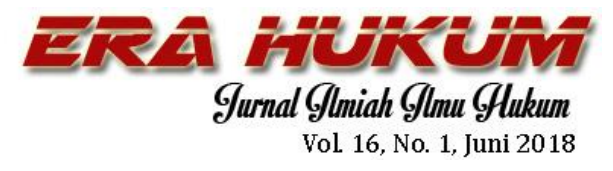

mengambil aksi kolektif. Intervensi

militer dapat dilakukan oleh koalisi

temporer atau negara secara individual

dengan menggunakan ketentuan-

ketentuan yang sudah disepakati.

Dinyatakan dalam ketentuan yang

kedua bahwa:

"Military Intervention for human protection purposes is justified in order halt or avert, a) large scale of loss of life, actual or apprehended, with genocidal intent or not, which is the product either of deliberate states action, or state neglect or inability to act, or a failed state situation or, b) large scale "ethnic cleansing" actual or apprehended, whether carried out by killing, forced expulsion, acts of terror or rape." ${ }^{45)}$

Intervensi militer untuk tujuan kemanusiaan dibenarkan apabila dilakukan untuk menghentikan atau mencegah, pertama, hilangnya

45) Ibid.

46) Statuta Mahkamah Pidana Internasional, Pasal 6 mengenai definisi genosida; "For the purpose of this Statute, "Genocide means any of the following acts commited with intent to destroy, in whole or in part, a national, ethnical, racial or religious group, as such:

a. Killing members of the group;

b. Causing serious bodily or mental harm to members of the group;

c. Deliberately inflicting on the group conditions of life calculated to bring about its physical destruction in whole or in part;
Teddy Nurcahyawan \& Lauw Wisnu Efektivitas Sanksi Dewan Keamanan Perserikatan Bangsa-bangsa...

kehidupan berskala besar yang secara nyata atau kelihatan seperti nyata baik dengan adanya keinginan untuk melakukan genosida ${ }^{46)}$ maupun tidak, yang merupakan produk ketidaksengajaan suatu negara atau pengabaian negara atau ketidakmampuan negara untuk bertindak atau keadaan "failed state" atau, b) “ethnic cleansing" atau permusnahan suatu etnis dalam skala yang besar yang senyata-nyatanya terjadi atau yang nampaknya terjadi, apakah dijalankan melalui pembunuhan, pengusiran, tindakan teror atau pemerkosaan. Ketentuan yang ke tiga menyatakan bahwa:

"The primary purpose of the intervention must be to halt or avert human suffering. Occupation of territory may not be able to be avoided, but it should not be an

d. Imposing measures intended to prevent births within the group;

e. Forcibly transferring children of the group to another group.

47) John Baylis dan Steve Smith, The Globalization of the World Politics, Oxford University Press, Oxford, 1997, hal.397. "Failed States: States that have collapsed into civil war and disorder and where the government of the state has ceased to exist inside the territorial borders of the state. Citizens find themselves in a quasi-state of nature." 


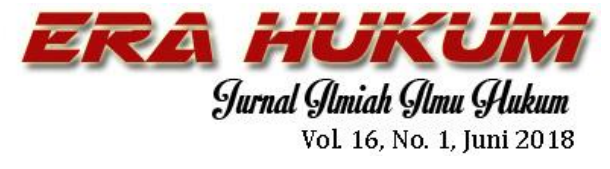

objective as such, and there should be a clear commitment from the outset to returning the territory to its souvereign owner at the consclusion of hostilities or, if this is impossible, admistering it on an intern basis under UN auspices. "48)

\section{Teori Efektivitas Hukum}

Efektivitas mengandung arti keefektifan pengaruh efek keberhasilan atau kemanjuran/kemujaraban, membicarakan keefektifan hukum tentu tidak terlepas dari penganalisisan terhadap karakteristik dua variabel terkait yaitu: karakteristik/dimensi dari obyek sasaran yang dipergunakan. ${ }^{49)}$

Hal yang dapat dilakukan untuk mengukur sejauh mana efektivitas dari hukum, kita pertama-tama harus dapat mengukur sejauh mana aturan hukum itu ditaati atau tidak ditaati. Jika suatu aturan hukum ditaati oleh sebagian besar target yang menjadi sasaran ketaatannya maka akan dikatakan aturan hukum yang bersangkutan adalah

48) Füsun Türkmen, Loc. Cit.

49) Barda Nawawi Arief, Kapita Selekta Hukum Pidana, cetakan Ketiga, Citra Aditya Bandung, 2013, Hal 67.

50) Salim, H.S dan Eris Septiana Nurbani, Penerapan Teori Hukum Pada Tesis dan
Teddy Nurcahyawan \& Lauw Wisnu Efektivitas Sanksi Dewan Keamanan Perserikatan Bangsa-bangsa...

efektif.50)

Derajat dari efektivitas hukum menurut Soerjono Soekanto, ditentukan oleh taraf kepatuhan masyarakat terhadap hukum, termasuk para penegak hukumnya, sehingga dikenal asumsi bahwa, "taraf kepatuhan yang tinggi adalah indikator suatu berfungsinya suatu sistem hukum, dan berfungsinya hukum merupakan pertanda hukum tersebut mencapai tujuan hukum yaitu berusaha untuk mempertahankan dan melindungi masyarakat dalam pergaulan hidup." ${ }^{51)}$

Pandangan lain tentang efektivitas hukum oleh Clarence J Dias mengatakan bahwa:

"An effective legal sytem may be described as one in which there exists a high degree of congruence between legal rule and human conduct. Thus and an effective kegal sytem will be characterized by minimal disparity between the formal legal system and the operative legal system is secured by: ${ }^{52)}$

Disertasi, Edisi Pertama, cet Kesatu, Rajawali Press, Jakarta, hal. 375.

51) Soerjono Soekanto, Efektivitas Hukum dan Peranan Saksi, Remaja Karya Bandung, 1985, hal. 7.

52) Clerence J. Dias. Research on Legal Service and Poverty: its Relevance to the Design of 


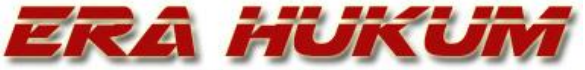 Gurnal Glmiah Glmu Glukum \\ Vol 16, No. 1, Juni 2018}

1. The intelligibility of it legal system.

2. High level public knowlege of the content of the legal rules

3. Efficient and effective mobilization of legal rules:

a. Acommited administration and.

b. Citizen involvement and participation in the mobilization process

4. Dispute sattelment mechanisms that are both easily accessible to the public and effective in their resolution of disputes and.

5. A widely shared perception by individuals of the effectiveness of the legal rules and institutions.

Pendapat tersebut dijelaskan

Clarence J Dias dalam Marcus Priyo

Guntarto $^{53)}$ sebagai berikut, terdapat 5

(lima) syarat bagi efektif tidaknya satu

sistem hukum meliputi:

1. Mudah atau tidaknya makna isi aturan-aturan itu ditangkap.

2. Luas tidaknya kalangan di dalam masyarakat yang mengetahui isi aturan- aturan yang bersangkutan.

3. Efisien dan efektif tidaknya mobilisasi aturan-aturan

Legal Service Program in Developing Countries, Wash. U.L., 1975, hal. 150

53) Ibid.
Teddy Nurcahyawan \& Lauw Wisnu Efektivitas Sanksi Dewan Keamanan Perserikatan Bangsa-bangsa...

hukum dicapai dengan bantuan aparat administrasi yang menyadari melibatkan dirinya kedalam usaha mobilisasi yang demikian, dan para warga masyrakat yang terlibat dan merasa harus berpartisipasi dalam proses mobilisasi hukum.

4. Adanya mekanisme penyelesaian sengketa yang tidak hanya harus mudah dihubungi dan dimasukan oleh setiap warga masyarakat, akan tetapi harus cukup efektif menyelesaikan sengketa.

5. Adanya anggapan dan pengakuan yang cukup merata di kalangan warga masyarakat yang beranggapan bahwa aturan-atauran dan pranatapranata hukum itu memang sesungguhnya berdaya mampu efektif.

Soerjono Soekanto menjelaskan bahwa dalam sosiologi hukum masalah terkait kepatuhan atau ketaatan terhadap kaidah-kaidah hukum pada umumnya telah menjadi faktor yang pokok dalam mengukur efektif tidaknya sesuatu yang ditetapkan dalam hukum ini. ${ }^{54)}$

Efektivitas Hukum yang

54) Soerjono Soekanto, Sosiologi, Suatu Pengantar, Rajawali Pers, Bandung, 1996, hal. 20. 


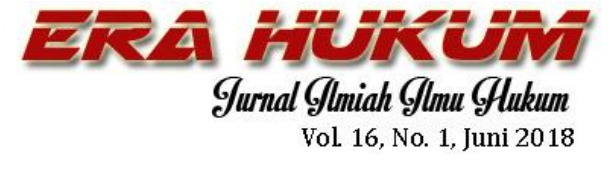

dikemukakan oleh Anthoni Allot sebagaimana dikutip Felik adalah sebagai berikut:

"Hukum akan menjadi efektif jika tujuan keberadaan dan penerapannya dapat mencegah perbuatan-perbuatan yang tidak diinginkan dapat menghilangkan kekacauan. Hukum yang efektif secara umum dapat membuat apa yang dirancang dapat diwujudkan. Jika suatu kegelapan maka kemungkinan terjadi pembetulan secara gampang jika terjadi keharusan untuk melaksanakan atau menerapkan hukum dalam suasana baru yang berbeda, hukum akan sanggup menyelesaikan." ${ }^{55)}$

Keberlakuan hukum berarti bahwa orang bertindak sebagaimana seharusnya sebagai bentuk kepatuhan dan pelaksana norma jika validitasnya adalah kualitas hukum, maka keberlakuan adalah kualitas perbuatan manusia sebenaranya bukan tentang hukum itu sendiri. ${ }^{56)}$ Selain itu William Chamblish dan Robert B Seidman

55) Salim H.S. dan Erlis Septiana Nurbani, Op.Cit, hal. 303.

56) Hans Kelsen, General Theory of Law and State, Diterjemahkan oleh Anders Wedberg, Russel and Russel, New York, 1991, dikutip dari Jimly Ashidiqqie dan M ali Safa'at, Teori Hans Kelsen Tentang Hukum, cet kedua, Konstitusi Press, Jakarta, 2012, hal. 39-40.
Teddy Nurcahyawan \& Lauw Wisnu Efektivitas Sanksi Dewan Keamanan Perserikatan Bangsa-bangsa...

mengungkapkan bahwa bekerjanya hukum dimasyarakat dipengaruhi oleh all other societal personal force (semua kekuatan dari individu masyarakat) yang melingkupi seluruh proses. ${ }^{57)}$

Bustanul Arifin yang dikutip oleh Raida L Tobing dkk, mengatakan bahwa dalam negara yang berdasarkan hukum, berlaku efektifnya sebuah hukum apabila didukung oleh tiga pilar, yaitu: ${ }^{58)}$

a. Lembaga atau penegak hukum yang berwibawa dapat diandalkan

b. Peraturan hukum yang jelas sistematis.

c. Kesadaran hukum masyarakat tinggi.

\section{E. Tinjauan Mengenai Konflik Bersenjata di Suriah}

Berikut ini tinjauan mengenai konflik bersenjata di Suriah.

\footnotetext{
57) Robert B Seidman, Law Order and Power, Adition Publishing Company Wesley Reading Massachusett, Massachusett, 1972, hal. 9-13.

58) Raida L. Tobing, dkk, Efektivitas UndangUndang Money Laundering, Badan Pembinaan Hukum Nasional, Kementrian Hukum dan HAM RI, Jakarta, 2011, hal. 11.
} 


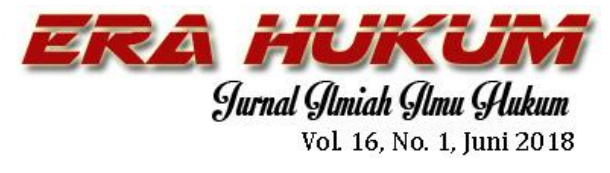

1. Negara Republik Arab Suriah Secara Umum

Suriah adalah sebuah Negara Dataran Subur, berpegunungan tinggi dan padang pasir. Negara bagi berbagai etnis dan agama yang di antaranya Alawite, Sunni, dan Kristen Arab, Armenia, Assyria, Druze, Kurdi, dan Turki. Muslim Arab Sunni merupakan kelompok penduduk terbesar (Mayoritas) di Suriah. Negara Suriah modern didirikan setelah Perang Dunia Pertama sebagai mandat Perancis. Suriah merdeka sebagai suatu negara Parlementer pada April 1946. Pasca kemerdekaan itu, Suriah mengalami kekacauan yang sebagian besar disebabkan oleh upaya kudeta, pada periode 1949-1971. Suriah juga pernah terlibat dalam Perang Arab-Israel pada tahun 1948, bersama negara-negara Arab lainnya berusaha untuk mencegah pembentukan negara Israel. November 1956, sebagai akibat langsung dari krisis Suez, Suriah menandatangani

59) https://tirto.id/mesir-dan-suriah-menjadisatu-dalam-republik-persatuan-arab-cjxe, Diakses pada tanggal 12 Juli 2017, Pukul 16:30 WIB.
Teddy Nurcahyawan \& Lauw Wisnu Efektivitas Sanksi Dewan Keamanan Perserikatan Bangsa-bangsa...

perjanjian dengan Uni Soviet sehingga terjadi pertukaran untuk peralatan militer. Meningkatnya kekuatan militer Suriah membuat Turki gerah.

Antara 1958 dan 1961, Suriah bersatu sementara dengan Mesir (United Arab Republic), yang diakhiri oleh kudeta militer. ${ }^{59}$ Suriah berada di bawah Undang-Undang Darurat 19632011. Tahun 1967, Suriah berperang melawan Israel. Tahun 1973, Suriah dan Mesir memprakarsai Perang Yom Kippur melawan Israel. ${ }^{60}$ Bashar alAssad menjadi presiden sejak tahun 2000 dan didahului oleh ayahnya yang bernama Hafez al-Assad (1970-2000). Pada tanggal 5 Oktober 2003, Israel membom sebuah tempat di dekat Damaskus, dan mengklaim itu adalah fasilitas pelatihan teroris bagi anggota Jihad Islam. Pada bulan Maret 2004, etnis Kurdi Suriah dan Arab bentrok di timur laut kota al-Qamishli. Pada tahun 2005, Suriah mengakhiri pendudukannya di atas Lebanon. Sejak

\footnotetext{
60) http://kisahmuslim.com/5927-10-ramadhankoalisi-negara-arab-menyerang-israel.html, Diakses pada tanggal 12 Juli 2017, Pukul 16:32 WIB.
} 


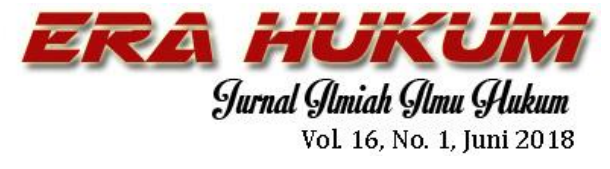

Maret 2011, Suriah telah terlibat dalam perang saudara. Perang sipil Suriah yang sedang berlangsung hingga saat ini, terinspirasi oleh Revolusi Arab Spring. ${ }^{61)}$

\section{Konflik Bersenjata di Suriah}

Suriah, suatu negara yang terletak di Timur Tengah ini pada mulanya berada dalam keadaan yang damai. ${ }^{62)}$ Konflik bersenjata di Suriah berawal dari adanya aksi unjuk rasa yang dilakukan oleh kelompok prodemokrasi yang menentang pihak penguasa Suriah pada 15 Maret 2011 di bagian selatan dari kota Deraa setelah adanya penangkapan dan penyiksaan terhadap beberapa remaja yang menggambar slogan-slogan revolusi di dinding sekolah. ${ }^{63)} 15$ orang remaja, yang semuanya masih berusia di bawah 17

\footnotetext{
${ }^{61) h t t p: / / w w w . m u s l i m e d i a n e w s . c o m / 2014 / 03 / s e ~}$ kilas-mengenal-negara-suriah-syria.html, Loc. Cit.

62) Spedaonthel, Krisis Suriah: AS, Inggris, Israel, Uni Eropa VS Rusia (Krisis Suriah Part-1), Artikel, 2013, hal.1.

63) http://www.bbc.com/news/world-middleeast-26116868, diakses pada tanggal 8 Juni 2017, Pukul 23:09 WIB.

64) Frederik C. Hoff and Alex Simon, 2013, "Sectarian Violence in Syria's Civil War :
}

Teddy Nurcahyawan \& Lauw Wisnu Efektivitas Sanksi Dewan Keamanan Perserikatan Bangsa-bangsa...

tahun, ditangkap dan disiksa setelah diketahui menggambar slogan di dindingdinding sekolah yang menjadi ciri khas dari Arab Spring: "The people want the fall of the regime". ${ }^{64)}$

Insiden ini memicu gelombang demonstrasi besar-besaran tanpa kekerasan, yang mana dalam demonstrasi tersebut warga Suriah menuntut keadilan atas rezim pemerintahan Bassar al-Assad. Pihak pemerintah menanggapi hal tersebut dengan penggunaan kekuatan bersenjata yang meluas dan semakin lebih kejam. Antara Februari dan Maret 2011, ribuan warga Suriah turun ke jalan-jalan untuk mengklaim hak-hak politik, sipil, dan ekonomi mereka. ${ }^{65)}$

Aksi demonstrasi tanpa kekerasan yang dilakukan oleh warga Suriah yang berubah menjadi keji mengakibatkan rezim pemerintahan Bashar al-Assad

Causes, Consequences, and Recommendations for Mitigation”, edisi Maret 2013, The Center for the Prevention of Genocide : United States Holocauts Memorial Museum, hal. 1.

${ }^{65)}$ Melanie De Groof, 2013, "Arms Transfers to The Syrian Arab Republic : Practice and Legality", Les Rapports du Grip, edisi September 2013, Groupe de Recherche ed d"Information Sur la Paix et la Securite (GRIP), hal. 1. 


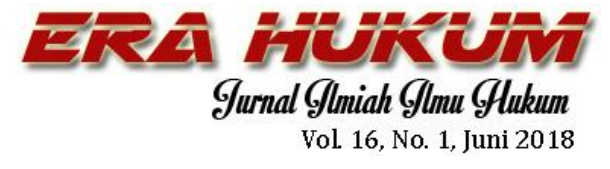

semakin gencar mengambil tindakan militer untuk membubarkan massa. ${ }^{66)}$ Setelah pasukan keamanan pemerintah menembaki para demonstran, membunuh beberapa di antara mereka, semakin banyak demonstran yang turun ke jalan-jalan. Pemerintah menggunakan kekuatan angkatan bersenjata untuk menghancurkan para demonstran. Sejak Juli 2011, ratusan ribu demonstran telah turun ke jalanjalan di sepanjang Suriah. Kelompok oposisi secara serentak mulai mengangkat senjata, pada awalnya untuk mempertahankan diri mereka dan kemudian untuk "membersihkan" pasukan angkatan bersenjata pemerintah dari wilayah mereka. ${ }^{67)}$

Bashar al-Assad menyatakan bahwa "banyak orang telah disesatkan pada awal terjadinya konflik, mereka

\footnotetext{
66) Melanie De Groof, Loc.Cit.

67) Ibid.

${ }^{68)}$ Pernyataan ini mendapat banyak kritikan dari berbagai pihak yang menyatakan bahwa pernyataan tersebut hanyalah merupakan kampanye propaganda dari rezim pemerintahan, dan tujuan utamanya ialah untuk mengambil tindakan yang kejam terhadap pihak oposisi Suriah. Elizabeth O'Bagy, 2012, "Jihad in Syria”, Middle East Security Report 6, edisi September 2012, Institute for the Study of War, hal. 9.
}

Teddy Nurcahyawan \& Lauw Wisnu Efektivitas Sanksi Dewan Keamanan Perserikatan Bangsa-bangsa...

berpendapat bahwa apa yang sebenarnya terjadi adalah kegemparan negara, sebagai akibat dari gelombang Arab Spring, namun hal tersebut bukanlah revolusi atau ,spring ${ }^{\text {ee }}$, hal ini merupakan tindakan terorisme dalam arti yang sesungguhnya" ${ }^{68)}$ Konflik di Suriah sekarang bukan hanya merupakan konflik antara pihak pemberontak melawan pihak Pemerintah Suriah. Konflik telah berkembang menjadi konflik sektarian, antara kelompok mayoritas Sunni melawan kelompok pihak Pemerintah Suriah yang beraliran Syiah, ${ }^{69}$ dan juga melibatkan kekuatan pihak regional dan dunia. ${ }^{70)}$ Kebangkitan para jihadis ISIS telah membawa konflik ke dimensi yang berbeda. ${ }^{71}$

Eskalasi kekerasan dan peningkatan konflik menjadi perang

${ }^{69)}$ Frederik C. Hoff and Alex Simon, Op.Cit., hal. 1-2.

70) Yang termasuk dalam kekuatan pihak regional dan dunia adalah Iran, Turki, Negaranegara Teluk Arab, Rusia dan Amerika Serikat. Christopher M. Blanchard, Carla E. Humud and Mary Berth D. Nikitin. Op.Cit., hal. 10.

71) http://www.bbc.com/news/world-middleeast-26116868, Loc.Cit. 


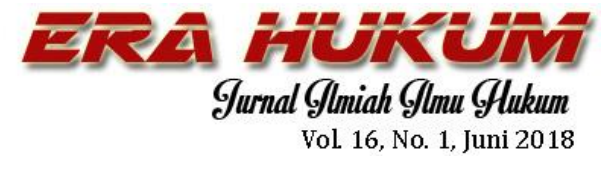

saudara $^{72)}$ di seluruh bagian negara dimulai dengan adanya peperangan antara pihak pemberontak dengan angkatan bersenjata pihak pemerintah untuk mengontrol seluruh bagianbagian kota di Suriah. Para pejuang berhasil menduduki ibukota Damaskus dan kota kedua terbesar, Aleppo, pada 2012. Sejak Juni 2013, PBB menyatakan bahwa 90.000 orang telah terbunuh selama konflik berlangsung. Sejak Agustus 2015, jumlahnya telah mencapai 250.000, menurut hasil laporan dari $\mathrm{PBB} .{ }^{73)}$ Sebagai akibat dari konflik, kondisi ekonomi di Suriah mengalami kemerosotan dan menurunnya nilai mata uang Suriah. Lebih jauh, banyak infrastruktur dasar termasuk sekolah-sekolah, rumahrumah sakit, tempat-tempat sumber air dan rumah-rumah telah, dan masih akan mengalami, penghancuran. ${ }^{74}$

72) Pada Juli 2012, International Committee of the Red Cross (ICRC) untuk pertama kalinya menyatakan bahwa Konflik Suriah merupakan "non-international armed conflict". Pada Agustus 2012, the UN Commission of Inquiry melaporkan bahwa selama periode pemberitaan (Februari 2012-Agustus 2012),"the intensity and duration of the conflict, combined with the increased organizational capabilities of antiGovernment armed groups, had met the legal
Teddy Nurcahyawan \& Lauw Wisnu Efektivitas Sanksi Dewan Keamanan Perserikatan Bangsa-bangsa...

Sejak bermulanya konflik, pihak regional dan internasional saling mempersenjatai masing-masing kelompok bersenjata yang berlawanan, yang menyebabkan Sekretaris Jenderal Perserikatan Bangsa-Bangsa (PBB) mengkualifikasikan konflik di Suriah sebagai "proxy war" "75) Laporan terakhir dari UN Independent International Commission of Inquiry on the Syrian Arab Republic telah secara pasti memantau bahwa semakin banyak aktor regional yang mendukung pergerakan pejuang dan persenjataan, peningkatan pada kelompok-kelompok sektarian, yang berakibat pada semakin meningkatnya tindak kekerasan di Suriah. ${ }^{76)}$

\section{Resolusi Dewan Keamanan PBB Nomor 2328 tertanggal 19 Desember 2016}

treshold of a non-international armed conflict". Melanie De Groof, Loc.Cit. Lihat juga BBC (2012), Syria in civil war, Red Cross sayse, 15 Juli 2012; Aljazeera, (2012), Red Cross declares Syria conflict a civil ware, 16 Juli 2012.

${ }^{73)}$ Christopher M. Blanchard, Carla E. Humud and Mary Berth D. Nikitin, Loc.Cit.

74) Melanie De Groof, Ibid.

75) Ibid.

76) Ibid. 


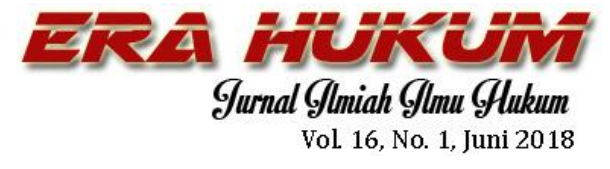

Pada tanggal 19 Desember 2016, Dewan Keamanan PBB mengeluarkan sebuah resolusi terkait konflik di Suriah yaitu resolusi Dewan Keamanan PBB Nomor 2328 dengan judul "The Situation in the Middle East (Syria)". ${ }^{77)}$ Resolusi tersebut dikeluarkan dengan suara bulat dari para anggota Dewan Keamanan PBB. ${ }^{78)}$ inti dari resolusi tersebut memberikan mandat bagi para pihak yang terlibat dalam konflik bersenjata di Suriah untuk memberikan bantuan terhadap masyarakat sipil.

Bantuan yang dimaksudkan dalam resolusi di atas adalah berupa bantuan untuk mengevakuasi masyarakat sipil di

77)

http://www.un.org/en/sc/documents/resolutions /2016.shtml, Diakses pada tanggal 28 Juni 2017, Pukul 21:22 WIB.

${ }^{78)}$ http://syriainstitute.org/calendar/unscadopts-resolutions-2328-2016-regardingmonitoring-of-aleppo-evacuation/, Diakses pada tanggal 28 Juni 2017, Pukul 21:10 WIB.

${ }^{79)}$ Data di United Nations Informations Centre, Jakarta, Resolusi Dewan Keamanan PBB Nomor 2328 Tahun 2016:

Poin 1.

Takes note of the efforts to carry out evacuations of civilians and fighters from the districts of the city of Aleppo affected by the conflict;

Poin 2.

Demands that all parties allow complete, immediate, unconditional, safe and unhindered access for the United Nations and its implementing partners, in order to ensure that
Teddy Nurcahyawan \& Lauw Wisnu Efektivitas Sanksi Dewan Keamanan Perserikatan Bangsa-bangsa...

Suriah yang menjadi korban pada konflik bersenjata di Suriah dan memberikan bantuan medis dengan fasilitas-fasilitas untuk mendukung pertolongan medis tersebut seperti rumah sakit, transportasi, dan sebagainya. ${ }^{79)}$

\section{Evakuasi Dan Bantuan Medis di}

\section{Suriah}

Krisis di Suriah telah merangkul pihak-pihak untuk terlibat di dalamnya. ${ }^{80)}$ Selama konflik bersenjata di Suriah berlangsung, beberapa pihak telah berperan untuk memberikan bantuan terhadap korban dari konflik tersebut, seperti World Health

humanitarian assistance reaches people through the most direct route in order to meet basic needs, including the provision of medical care, consistent with the provisions of its resolution 2258 (2015) for the whole of Syria and respect and protect all civilians across Aleppo and throughout Syria; stresses that all parties must respect their obligations under international humanitarian law and, in particular, to respect and protect civilians and civilian objects;

Poin 6.

Calls on all parties to respect and protect all medical and humanitarian personnel, their means of transport and equipment, as well as hospitals and other medical facilities throughout the country, consistent with its resolution 2286 (2016);

${ }^{80)}$ Spedaonthel, Op.Cit. 


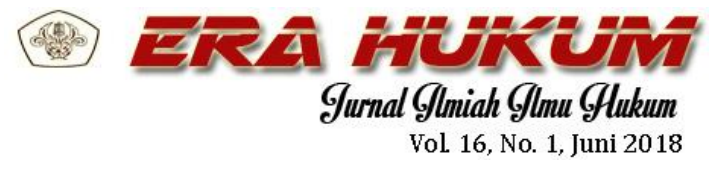

Organization (WHO) yang memberikan bantuan seperti evakuasi korban atas konflik Suriah tersebut. ${ }^{81)}$ Korban yang timbul akibat konflik di Suriah terus meningkat. $W H O$ sendiri tidak mampu untuk memberikan bantuan sehingga membutuhkan bantuan dalam skala yang lebih besar dari berbagai pihak. ${ }^{82)}$

Menurut laporan tahunan $I C R C$, dalam tahun 2013 ICRC bersama dengan SARC telah memberikan bantuan medis, serta 20 juta orang bisa mendapatkan air bersih, lebih dari 3,5 juta orang mendapatkan makanan, dan lebih dari 1 juta orang mendapatkan kebutuhan rumah tangga melalui National Society/ICRC Action. ${ }^{83)}$ Pada laporan ICRC dan SARC pada bulan Maret 2013, ICRC bersama dengan

81)

https://www.ncbi.nlm.nih.gov/pmc/articles/PM C3697421/\#ref7, Diakses pada tanggal 30 Juni 2017, Pukul 13:02 WIB.

82) World Health Organization, regional office of Eastern Mediterranean, Situation reports for the Syrian Arab Republic,

http://www.emro.who.int/images/stories/eha/do cuments/Sitrep_7_for_the_Web.pdf . Diakses pada tanggal 30 Juni 2017, Pukul 13:08 WIB.

83) ICRC Annual Report, Syrian Arab Republic, hal. 1.

84) Jordan Menerima sebanyak 584.600 pengungsi, Lebanon sebanyak 962.385 pengungsi, Turki menerima sebanyak 634.901
Teddy Nurcahyawan \& Lauw Wisnu Efektivitas Sanksi Dewan Keamanan Perserikatan Bangsa-bangsa...

$S A R C$ berhasil mengungsikan warga Suriah sebanyak 2.513.654 orang di Jordan, Lebanon, Turki, Irak, Mesir dan Afrika Utara. ${ }^{84)}$

Serangan di Suriah terus memburuk, bahkan terjadi penyerangan terhadap pasien (mencapai ribuan), para petugas medis, serta pengrusakan fasilitas-fasilitas medis. ${ }^{85}$ Pada tahun 2015, WHO mengumumkan bahwa $60 \%$ fasilitas medis telah rusak atau hancur, sementara 25.000 orang terluka setiap bulan. ${ }^{86)}$

Pada tanggal 23 Desember 2016, sekitar 10.000 warga dari Aleppo Timur di Suriah yang berharap telah berhasil dievakuasi. ${ }^{87)}$ Juru Bicara ICRC menyatakan bahwa seluruh warga yang berharap untuk dievakuasi dan yang

pengungsi, Irak menerima sebanyak 224.356 pengungsi, Mesir dan Afrika Utara menerima sebanyak 134.534 pengungsi. ICRC and SARC Movement Report, Syria and Countries Affected by the Conflict: Humanitarian Situation, Needs and Response, 2013, hal. 2. 85) https://www.icrc.org/en/document/hcidstatement, Diakses pada tanggal 30 Juni 2017, Pukul 13:30 WIB.

86) Ibid.

${ }^{87)}$ https://news.detik.com/internasional/d3378767/evakuasi-di-aleppo-telah-tuntas, Diakses pada tanggal 30 Juni 2017, Pukul 14:42 WIB. 


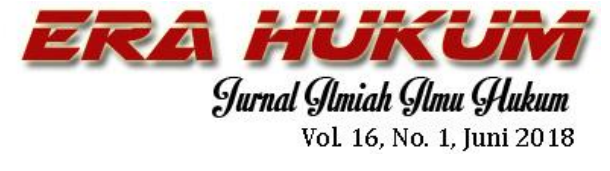

terluka berhasil dievakuasi secara tuntas. ${ }^{88)}$ Pada tanggal 13 Februari 2017, terjadi lagi serangan terhadap penduduk sipil, fasilitas dan petugas medis di bagian selatan Suriah, yaitu rumah sakit Dara'a al Balad mengakibatkan 52 orang meninggal dunia dan satu di antaranya adalah seorang perawat. ${ }^{89)}$

Berdasarkan hasil wawancara penulis dengan Ibu Ratna Juwita (Dosen Hukum Internasional di Universitas Atma Jaya Yogyakarta) penulis mendapat informasi bahwa tolak ukur efektivitas suatu Resolusi Dewan Keamanan Perserikatan Bangsa-Bangsa dapat diukur dari terlaksananya poinpoin yang tercantum dalam resolusi tersebut. Sampai sejauh manakah keberhasilan pelaksanaan dari isi resolusi tersebut dengan melihat fakta di lapangan. Meskipun nantinya pelaksaan Resolusi tersebut tidak dapat dilaksanakan secara maksimal, dapat dilihat pula dari upaya-upaya yang telah

${ }^{88)}$ https://news.detik.com/internasional/d3378767/evakuasi-di-aleppo-telah-tuntas, Ibid. 89)

https://defendmedicalimpartiality.org/?p=1868, Diakses pada tanggal 8 Juli 2017, Pukul 14:22 WIB.
Teddy Nurcahyawan \& Lauw Wisnu Efektivitas Sanksi Dewan Keamanan Perserikatan Bangsa-bangsa...

dilaksanakan untuk mencapai tujuan dari Resolusi tersebut

Terkait dengan Resolusi DK PBB Nomor 2328 ini, efektivitasnya dapat diukur dari pemberian bantuan, perlindungan terhadap penduduk sipil, petugas medis, fasilitas-fasilitas medis maupun publik yang dapat diupayakan untuk meminimalisir korban dan kerugian penduduk sipil, petugas medis dan fasilitas medis.

Resolusi Dewan Keamanan PBB Nomor 2328 yang dikeluarkan pada tanggal 19 Desember 2016 dengan judul "The Situation in the Middle East (Syria)" dengan suara bulat tanpa adanya veto dari salah satu anggota tetap Dewan Keamanan PBB. ${ }^{90)}$ Resolusi 2328 memberi mandat pada para pihak yang terkait dalam konflik bersenjata di Suriah untuk segera memberikan bantuan kemanusiaan kepada penduduk sipil yang menjadi korban dalam konflik Suriah dengan

90)

http://www.un.org/en/sc/documents/resolutions /2016.shtml, Diakses pada tanggal 28 Juni 2017, Pukul 21:22 WIB. 


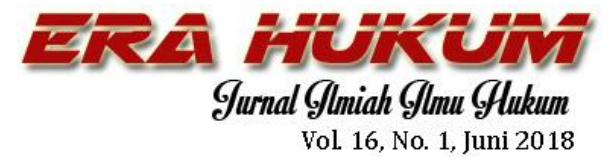

memberikan bantuan medis, fasilitasfasilitas medis seperti rumah sakit, transportasi, perlindungan terhadap para petugas medis, serta evakuasi para penduduk sipil Suriah yang menjadi korban. ${ }^{91)}$

\section{Efektivitas sanksi DK PBB}

Berikut adalah efektivitas Resolusi Dewan Keamanan PBB Nomor 2328 tahun 2016:

a. Poin pertama meminta pihak-pihak yang terkait dalam konflik di Suriah

91) Data di United Nations Informations Centre, Jakarta, Resolusi Dewan Keamanan PBB Nomor 2328 Tahun 2016:

Poin 1.

Takes note of the efforts to carry out evacuations of civilians and fighters from the districts of the city of Aleppo affected by the conflict;

Poin 2.

Demands that all parties allow complete, immediate, unconditional, safe and unhindered access for the United Nations and its implementing partners, in order to ensure that humanitarian assistance reaches people through the most direct route in order to meet basic needs, including the provision of medical care, consistent with the provisions of its resolution 2258 (2015) for the whole of Syria and respect and protect all civilians across Aleppo and throughout Syria; stresses that all parties must respect their obligations under international humanitarian law and, in particular, to respect and protect civilians and civilian objects;

Poin 6.

Calls on all parties to respect and protect all
Teddy Nurcahyawan \& Lauw Wisnu Efektivitas Sanksi Dewan Keamanan Perserikatan Bangsa-bangsa...

untuk mengevakuasi penduduk sipil dan para pejuang dari distrik kota Aleppo yang terkena dampak konflik. Pelaksanaan dari poin pertama ini sudah dilakukan oleh beberapa pihak seperti $W H O,{ }^{92)}$ ICRC bersama dengan SARC $C^{93)}$ yang telah melakukan evakuasi para korban dan penduduk sipil dari konflik di Suriah ke negara-negara seperti Jordan, Lebanon, Turki, Irak, Mesir dan Afrika Utara. ${ }^{94)}$ Bantuan evakuasi tersebut sudah dilakukan oleh sebagian pihak yang

medical and humanitarian personnel, their means of transport and equipment, as well as hospitals and other medical facilities throughout the country, consistent with its resolution 2286 (2016);

92)

https:/www.ncbi.nlm.nih.gov/pmc/articles/PM C3697421/\#ref7, Diakses pada tanggal 30 Juni 2017, Pukul 13:02 WIB.

93) Jordan Menerima sebanyak 584.600 pengungsi, Lebanon sebanyak 962.385 pengungsi, Turki menerima sebanyak 634.901 pengungsi, Irak menerima sebanyak 224.356 pengungsi, Mesir dan Afrika Utara menerima sebanyak 134.534 pengungsi. ICRC and SARC Movement Report, Syria and Countries Affected by the Conflict: Humanitarian Situation, Needs and Response, 2013, hal. 2.

94) Jordan Menerima sebanyak 584.600 pengungsi, Lebanon sebanyak 962.385 pengungsi, Turki menerima sebanyak 634.901 pengungsi, Irak menerima sebanyak 224.356 pengungsi, Mesir dan Afrika Utara menerima sebanyak 134.534 pengungsi. ICRC and SARC Movement Report, Syria and Countries Affected 


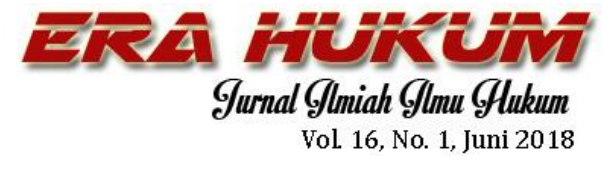

terkait dalam konflik bersenjata di Suriah, namun belum terlihat peran dari pihak-pihak lain khususnya para pihak terkait konflik Suriah yang ditujukan oleh Resolusi Dewan Keamanan Nomor 2328.

b. Poin ke dua juga menekankan terhadap para pihak terkait konflik di Suriah agar dapat memberi bantuan evakuasi secara sukarela dan sesuai dengan prinsip Hukum Humaniter Internasional dengan tetap memperhatikan tujuan utama mereka yaitu untuk mengevakuasi para penduduk sipil yang terdampak konflik dari Suriah ke negara-negara yang tidak terdampak konflik dengan evakuasi yang sukarela tanpa paksaan, serta memberikan perlindungan bagi para penduduk sipil yang menjadi korban dari konflik di Suriah. Menurut penulis meskipun telah banyak pihak yang telah berupaya keras untuk meminimalisir korban dari pihak penduduk sipil dan

by the Conflict: Humanitarian Situation, Needs and Response, 2013, hal. 2.
Teddy Nurcahyawan \& Lauw Wisnu Efektivitas Sanksi Dewan Keamanan Perserikatan Bangsa-bangsa...

mengevakuasi para penduduk sipil yang mau dievakuasi secara sukarela dari Suriah namun masih saja terdapat korban dari pihak penduduk sipil, yang seharusnya golongan penduduk sipil ini harus dan wajib dilindungi oleh Hukum Humaniter Internasional dan para pihak terkait konflik. Hal ini sebagaimana pernyatan dari Civilians in Conflict: ${ }^{95)}$

"Since US-led operations against ISIS began in 2014, we have engaged with the US government to ensure that policies are in place to minimize civilian harm and to track, investigate, and make amends to civilians harmed by operations in Iraq and Syria. While the capability to make amends in Iraq still exists due to previous US involvement there, we had to work to convince the US government to approve the making of amends for Syrian victims. We are also working to ensure that any training for the Syrian armed opposition incorporate measures to minimize civilian harm."

${ }^{95)}$ http://civiliansinconflict.org/ourwork/countries/syria/, Diakses pada tanggal 04 Agustus 2017, Pukul 13:04 WIB. 


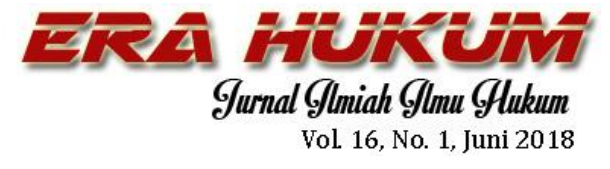

c. Poin ke tiga meminta Perserikatan Bangsa-Bangsa dan pihak-pihak lainnya yang terlibat dalam konflik bersenjata di Suriah untuk mengawasi distrik timur Aleppo dan distrik-distrik lainnya di kota itu. Pengawasan tersebut mulai dilakukan oleh PBB pada tanggal 21 Desember 2016, tepat 2 hari setelah Resolusi DK PBB Nomor 2328 dikeluarkan. ${ }^{96}$ poin ke tiga dapat dikatakan sudah dilaksanakan tanggap dan cepat oleh PBB seperti tujuan utama poin ke tiga Resolusi Nomor 2328 di atas. Syrian Observatory for Human Rights juga merupakan badan pengawas yang berperan dalam mengawasi keadaan yang terjadi di Suriah. ${ }^{97) .}$ Selain itu, yang menjadi salah satu alasan tertundanya evakuasi di distrik timur kota Aleppo karena begitu banyaknya jumlah penduduk

96)

http://www.antaranews.com/berita/602706/pbb -akan-kirim-20-pengamat-ke-aleppo-timur, Diakses pada tanggal 16 Juli 2017, Pukul 20:43 WIB.

97) https://news.detik.com/internasional/d3372153/sempat-tertunda-proses-evakuasi-
Teddy Nurcahyawan \& Lauw Wisnu Efektivitas Sanksi Dewan Keamanan Perserikatan Bangsa-bangsa...

sipil yang tinggal di sana diperkirakan sekitar 250.000 hingga 275.000 penduduk sipil dan pejuang yang masih bertahan di sana. Meskipun begitu, bantuan dari PBB masih tetap diberikan bagi para penduduk sipil dan pejuang di sana. ${ }^{98)}$

d. Poin ke empat menekankan pentingnya untuk memastikan kesukarelaan, keamanan, dan martabat penduduk sipil dari distrik timur Aleppo atau area lainnya, di bawah pengawasan dan koordinasi dari Perserikatan Bangsa-Bangsa dan institusi lainnya yang terkait. Pada poin ini, penulis berpendapat bahwa kesukarelaan dan keamanan penduduk sudah dipastikan oleh pihak-pihak yang memberikan pertolongan pada penduduk sipil di Suriah, khususnya dalam bantuan evakuasi, pihak-pihak yang

\footnotetext{
warga-sipil-dari-aleppo-dimulai, Diakses pada tanggal 17 Juli 2017, Pukul 16:04 WIB. 98)

http://www.independent.co.uk/voices/aleppobattle-latest-syria-civil-war-ceasefireevacuation-rebels-bashar-al-assad-turkeyrussia-iran-a7475296.html, Diakses pada tanggal 04 Agustus 2017, Pukul 13:22 WIB.
} 


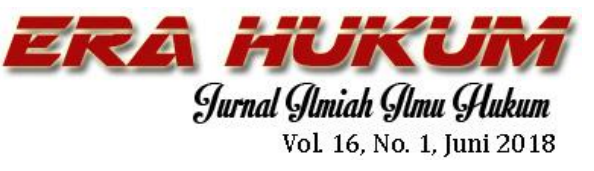

dievakuasi sebagian besar adalah pihak-pihak yang berharap untuk dievakuasi dan keamanan dari pemberian bantuan juga sudah dilaksanakan dengan baik melihat proses evakuasi berjalan dengan baik dan aman tanpa adanya kendala dan kekerasan. ${ }^{99)}$ Institusi lain yang banyak terkait dan berperan selama konflik Suriah ialah ICRC, sebagaimana dikutip dari laman icrc.org, ICRC bekerja sama dengan Syrian Arab Red Crescent telah berupaya untuk mengevakuasi dan memberikan bantuan salah satunya ialah sanitasi air bersih bagi para penduduk sipil yang terdampak konflik Suriah. Di bawah ini adalah kutipan yang diambil dari laman icrc.org: ${ }^{100)}$

Today, half of Syria's population is displaced either within the country or abroad. Over five million Syrians are cut off from basic supplies and services. Fighting continues to force thousands from their homes.

The ICRC is working with the Syrian Arab Red Crescent to

99) https://news.detik.com/internasional/d3378767/evakuasi-di-aleppo-telah-tuntas, Loc.Cit.
Teddy Nurcahyawan \& Lauw Wisnu Efektivitas Sanksi Dewan Keamanan Perserikatan Bangsa-bangsa...

provide clean water and improve sanitation, as well as distributing food and basic aid. Nearly half a million people have received household items such as kitchen sets, hygiene kits and winter clothes this year alone.

ICRC President Peter Maurer said: "While we can help people survive in a very difficult situation, I'm very concerned that we are here, again, moving into a long, longterm protracted conflict with no overall peace deal in sight."

So far this year, we've worked with the Syrian Arab Red Crescent to provide 1.3 million people, spread overten provinces, with food. Over $25 \%$ of those people were located in hard-to-reach or besieged areas. You can help us continue our life-saving work.

e. Poin ke lima meminta semua pihak untuk memberi izin penuh dan memberikan akses tanpa hambatan kepada Perserikatan BangsaBangsa dan sekutu pelaksana, untuk memastikan bahwa bantuan kemanusiaan mencapai orangorang melalui rute tercepat dalam

\footnotetext{
100) https://www.icrc.org/en/document/syrianwar-latest-news, Diakses pada tanggal 4 Agustus 2017, Pukul 13:25 WIB.
} 


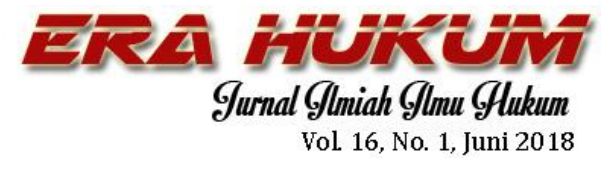

rangka memenuhi kebutuhan dasar termasuk penyediaan pelayanan medis kepada seluruh wilayah Suriah dan menghormati serta melindungi seluruh penduduk sipil di sepanjang Aleppo di seluruh wilayah Suriah.

Poin ke lima menurut penulis telah dipenuhi dengan pemberian bantuan oleh pihak-pihak yang telah memberikan bantuan yang telah memberikan bantuan tanpa adanya hambatan dan kekerasan, bahkan dengan persetujuan dengan pihak pemerintah Suriah sendiri sehingga akses dan keamanan telah terjamin dalam pemberian bantuan ini. ${ }^{101)}$ Pemberian bantuan medis berupa fasilitas-fasilitas medis sudah dilaksanakan, tetapi keamanan dari fasilitas medis dan petugas medis masih belum diawasi secara optimal dengan adanya serangan-serangan pada fasilitas-

101)

http://edition.cnn.com/2017/04/14/middleeast/s yria-evacuations/index.html, Diakses pada tanggal 17 Juli 2017, Pukul 16:08 WIB.
Teddy Nurcahyawan \& Lauw Wisnu Efektivitas Sanksi Dewan Keamanan Perserikatan Bangsa-bangsa...

fasilitas dan petugas medis setelah Resolusi DK PBB Nomor 2328 dikeluarkan. ${ }^{102)} \quad$ Penyerangan terhadap petugas-petugas dan fasilitas medis yang dikirim oleh PBB, ICRC, serta SARC masih sering terjadi dalam wilayah konflik suriah, sebagaiaman yang termuat dalam laman icrc.org:

f. Poin ke enam memanggil semua pihak untuk menghormati dan melindungi seluruh petugas medis dan kemanusiaan, sarana transportasi dan perlengkapan mereka, seperti rumah sakit dan fasilitas-fasilitas medis lainnya di seluruh negara. Poin ini telah dilaksanakan oleh pihak-pihak terkait dalam konflik Suriah, seperti membangun rumah sakit Avicenna di kota Idlib yang bertujuan untuk memberikan pengamanan bagi penduduk sipil, fasilitas medis, serta petugas medis yang menjalankan tugasnya di Suriah. ${ }^{103)}$

\footnotetext{
102) https://www.icrc.org/en/document/hcidstatement, Op.Cit. 103)

https://m.tempo.co/read/news/2017/07/23/1158 93638/rumah-sakit-bawah-tanah-perlindu ngan-
} 


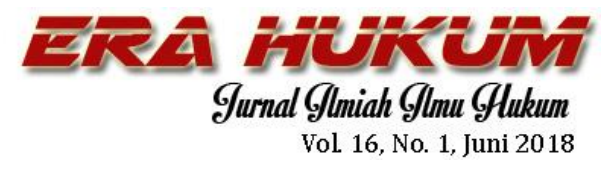

Setelah dikeluarkannya Resolusi

DK PBB Nomor 2328, serangan terhadap fasilitas-fasilitas medis dan petugas medis masih terjadi, ${ }^{104)}$ sehingga penulis berpendapat bahwa poin ke enam ini sudah dilaksanakan oleh para pihak terkait dengan upaya-upaya terbaik dan serangan yang terjadi pada praktiknya bukanlah hal yang mudah untuk diantisipasi secara sempurna.

g. Poin ke tujuh meminta Sekretaris Jenderal untuk mengambil langkah penting untuk membuat pengaturan, termasuk pengaturan keamanan dalam berkonsultasi dengan pihak yang berkepentingan,

terakhir-paramedis-suriah, diakses pada tanggal 4 Agustus 2017, Pukul 13:16 WIB.

104) Ibid.

105) Statement by the Secretary-General on Syria

For six years now, the Syria people have been victims of one of the worst conflicts of our time.

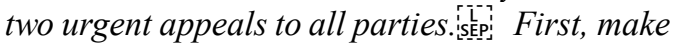
the most of the 30 December 2016 ceasefire established by the guarantors of the Astana meetings, enhance it further, and ensure that humanitarian aid can reach all those in need in Syria without any obstacles and impediments. Second, all those with influence on the parties to the conflict must strive to overcome their differences and work together to put an end to
Teddy Nurcahyawan \& Lauw Wisnu Efektivitas Sanksi Dewan Keamanan Perserikatan Bangsa-bangsa...

untuk mengizinkan observasi oleh Perserikatan Bangsa-Bangsa dan institusi lainnya yang terkait dengan kesejahteraan penduduk sipil, dengan penuh hormat pada hukum humaniter internasional, di dalam distrik timur kota Aleppo; memberitahu Dewan Keamanan mengenai pengaturan tersebut dan untuk membawa aktivitas yang disebutkan di atas segera setelah itu. Sekretaris Jenderal PBB telah membuat aturan untuk mengakhiri konflik bersenjata di Suriah ${ }^{105)}$ dan membuat kesepakatan dengan Pihak Pemerintah Suriah terkait keamanan penduduk di Suriah. ${ }^{106)}$ Poin ke tujuh ini telah dilaksanakan

the conflict, namely contributing to the success of the intra-Syrian negotiations in Geneva on the basis of the Geneva communique and relevant Security Council resolutions, including resolution 2254 (2015). Peace in Syria is a moral and political imperative both for the Syrian people and for the world -- an imperative that

cannot

wait.https://www.un.org/sg/en/content/sg/state ment/2017-03-15/statement-secretary-generalsyria, Diakses pada tanggal 17 Juli 2017, Pukul 16:23 WIB.

106) http://www.reuters.com/article/us-mideastcrisis-syria-un-idUSKBN181006, Diakses pada tanggal 17 Juli 2017, Pukul 16:25 WIB. 


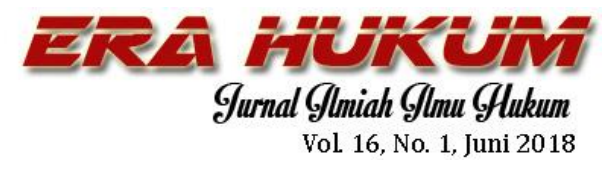

dengan baik oleh Sekretaris

Jenderal PBB.

h. Poin ke delapan menyatakan permintaan lebih lanjut kepada

Sekretaris Jenderal untuk melapor pada Dewan Keamanan dalam pengimplementasian resolusi ini, termasuk oleh pihak di lapangan, dalam 5 hari setelah resolusi ini di adopsi. Penulis tidak menemukan adanya laporan dari Sekretaris Jenderal PBB dalam 5 hari setelah dikeluarkannya Resolusi DK PBB Nomor 2328, sehingga poin ke delapan belum dilaksanakan, tetapi Sekretaris Jenderal tetap berperan aktif dalam mengatasi konflik bersenjata di Suriah ${ }^{107)}$ dengan adanya peraturan dan kesepakatan yang dicapai dengan pihak pemerintah Suriah. ${ }^{108)}$

i. Poin ke sembilan meminta para pihak agar tetap aktif dalam

107)

https://www.un.org/sg/en/content/sg/statement/ 2017-03-15/statement-secretary-general-sy ria, Loc. Cit.

108) http://www.reuters.com/article/us-mideastcrisis-syria-un-idUSKBN181006, Loc.Cit.

109) https://www.icrc.org/en/where-wework/middle-east/syria, Diakses pada tanggal 4 Agustus 2017, Pukul 13:22 WIB.
Teddy Nurcahyawan \& Lauw Wisnu Efektivitas Sanksi Dewan Keamanan Perserikatan Bangsa-bangsa...

menangkap masalah terkait konflik bersenjata di Suriah. Dalam poin ini penulis melihat beberapa pihak telah berperan aktif dalam konflik di Suriah seperti ICRC bersama dengan $S A R C$ yang sangat berperan aktif memberikan bantuan sampai saat penulisan hukum skripsi ini, ${ }^{109)}$ Sekretaris Jenderal PBB, beberapa negara lain seperti Amerika Serikat dan Perancis ${ }^{110)}$ dan pihak-pihak lain yang terus berperan dengan memberikan bantuan medis, donasi, serta bantuan evakuasi dan penerimaan pengungsi yang merupakan penduduk sipil Suriah sebagai korban konflik yang dievakuasi.

Penulis menilai Resolusi Dewan Keamanan PBB Nomor 2328 sudah dilaksanakan dengan upaya-upaya dari pihak-pihak yang terkait seperti ICRC

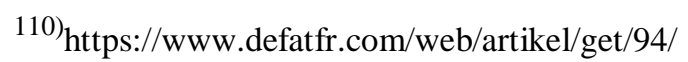
hadir-dalam-dialog-suriah-perancis-ikut-sep akati-penghentian-kekerasan-dan-penyaluranbantuan, Diakses pada tanggal 4 Agustus 2017, Pukul 13:31 WIB. 


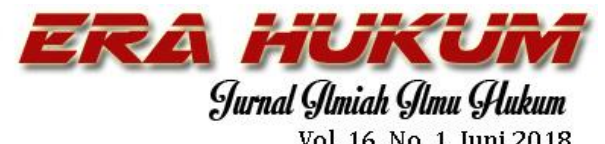

Vol 16, No. 1, Juni 2018
Teddy Nurcahyawan \& Lauw Wisnu Efektivitas Sanksi Dewan Keamanan Perserikatan Bangsa-bangsa... bersama dengan $S A R C$, Amerika Serikat dan Perancis, dan pihak lainnya, namun hasilnya belum optimal, kendalanya terdapat pada permasalahan di lapangan masih terjadi pelanggaran-pelanggaran seperti serangan terhadap penduduk sipil, fasilitas medis, petugas medis yang menjalankan tugasnya. Menurut penulis, serangan yang terjadi bukanlah hal yang mudah untuk diantisipasi. Penulis melihat dari sisi pelaksanaan Resolusi DK PBB Nomor 2328 tersebut sehingga menurut pendapat penulis, Resolusi tersebut sudah dilaksanakan dengan beragam upaya dari para pihak.

\begin{tabular}{|l|c|c|}
\hline Poin Resolusi & $\begin{array}{c}\text { Sudah } \\
\text { dilaksana- } \\
\text { kan }\end{array}$ & $\begin{array}{c}\text { Belum } \\
\text { dilaksana- } \\
\text { kan }\end{array}$ \\
\hline $\begin{array}{l}\text { 1. } \\
\text { Meminta pihak- } \\
\text { pihak terkait untuk } \\
\text { mengevakuasi } \\
\text { korban. }\end{array}$ & $\sqrt{ }$ & - \\
\hline 2. & $\begin{array}{l}\text { Melakukan secara } \\
\text { evakuasi } \\
\text { sukarela dan sesuai } \\
\text { dengan prinsip Hk }\end{array}$ & $\sqrt{ }$ \\
$\begin{array}{l}\text { Humaniter } \\
\text { Internasional. }\end{array}$ & & \\
\hline 3. $\begin{array}{l}\text { Meminta PBB dan } \\
\text { pihak terkait untuk } \\
\text { mengawasi distrik } \\
\text { timur Aleppo secara } \\
\text { tanggap. }\end{array}$ & $\sqrt{ }$ & - \\
\hline 4. $\begin{array}{l}\text { Memastikan } \\
\text { kesukarelaan, } \\
\text { keamanan dan } \\
\text { martabat penduduk } \\
\text { sipil di distrik timur }\end{array}$ & & \\
\hline
\end{tabular}

\begin{tabular}{|c|c|c|c|}
\hline & $\begin{array}{l}\text { Aleppo dan wilayah } \\
\text { lainnya. }\end{array}$ & & \\
\hline 5. & $\begin{array}{lr}\text { Meminta } & \text { semua } \\
\text { pihak } & \text { untuk } \\
\text { memberi izin penuh } \\
\text { dan akses } & \text { tanpa } \\
\text { hambatan pada PBB } \\
\text { dan r sekutu } \\
\text { pelaksana untuk } \\
\text { memberikan } \\
\text { bantuan. }\end{array}$ & $\sqrt{ }$ & - \\
\hline & $\begin{array}{l}\text { Memanggil semua } \\
\text { pihak untuk } \\
\text { menghormati dan } \\
\text { melindungi seluruh } \\
\text { petugas medis dan } \\
\text { fasilitas2 medis }\end{array}$ & $\sqrt{ }$ & - \\
\hline & $\begin{array}{l}\text { Meminta } \\
\text { untuk mengambil } \\
\text { langkah penting } \\
\text { untuk membuat } \\
\text { pengaturan, } \\
\text { termasuk untuk } \\
\text { pengaturan } \\
\text { keamanan dan } \\
\text { berkonsultasi } \\
\text { dengan pihak yang } \\
\text { berkepentingan, } \\
\text { untuk mengizinkan } \\
\text { PBB untuk } \\
\text { mengobservasi dan } \\
\text { institusi lainnya } \\
\text { untuk kesejahteraan } \\
\text { penduduk sipil di } \\
\text { distrik timur kota } \\
\text { Aleppo. }\end{array}$ & $\sqrt{ }$ & - \\
\hline & $\begin{array}{l}\text { Meminta Sekjen } \\
\text { melapor pada DK } \\
\text { untuk melapor pada } \\
\text { DK terkait } \\
\text { pengimplementasia } \\
\text { n Resolusi ini. }\end{array}$ & - & $\sqrt{ }$ \\
\hline & $\begin{array}{l}\text { Meminta para pihak } \\
\text { untuk berperan aktif } \\
\text { dalam menangkap } \\
\text { masalah terkait } \\
\text { konflik bersenjata di } \\
\text { Suriah. }\end{array}$ & $\sqrt{ }$ & - \\
\hline
\end{tabular}

Tabel 1.

Rekapitulasi Poin Resolusi Dewan Keamanan PBB yang Sudah Dilaksanakan 


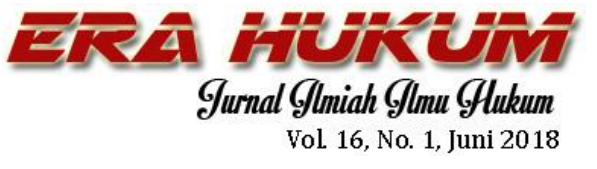

Apabila kita menelaah tolak ukur tersebut dengan Resolusi Dewan Keamanan PBB Nomor 2328 tahun 2016, poin-poin di atas sudah terpenuhi, yaitu:

1. Kejelasan makna dari isi Resolusi untuk dipahami oleh sebagian besar pihak yang ditujukan.

2. Luasnya masyarakat yang mengetahui isi dari Resolusi tersebut. Para anggota PBB sudah seharusnya mengetahui isi dari Resolusi tersebut, serta pihak-pihak terkait seharusnya mengetahui adanya Resolusi tersebut ketika dikeluarkan.

3. Mobilisasi dari Resolusi tersebut.

4. Kesadaran hukum yang tinggi dari pihak-pihak yang terkait khususnya bagi negara-negara anggota PBB.

5. Lembaga atau penegak hukum yang berwibawa dan dapat diandalkan.
Teddy Nurcahyawan \& Lauw Wisnu Efektivitas Sanksi Dewan Keamanan Perserikatan Bangsa-bangsa...

6. Adanya pengakuan yang cukup merata di kalangan masyarakat internasional khususnya negaranegara anggota PBB yang beranggapan bahwa aturan-aturan dan pranata-pranata hukum itu memang sesungguhnya berdaya mampu efektif.

Tolak ukur efektivitas yang dikemukakan oleh Soerjono Soekanto menurut penulis telah dipenuhi, karena merujuk pada penelitian dari penulis, banyak pihak yang memberikan bantuan setelah Resolusi Dewan Keamanan PBB Nomor 2328 dikeluarkan seperti ICRC bersama dengan SARC, serta negara lainnya seperti Amerika dan Perancis. Banyak pertolongan yang sudah dilakukan, salah satunya seperti evakuasi 


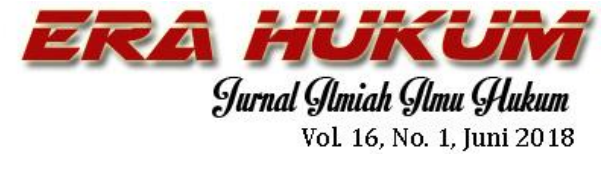

penduduk sipil di $\quad$ Suriah, ${ }^{111}$ perlindungan fasilitas dan petugas medis, serta bantuan-bantuan lainnya yang telah diuraikan oleh penulis di atas.

\section{PENUTUP}

Berdasarkan analisis yang telah dilakukan oleh penulis dengan mengaitkan teori dan data yang didapatkan terkait konflik bersenjata di Suriah, penulis menarik kesimpulan bahwa Resolusi Dewan Keamanan PBB Nomor 2328 tahun 2016 sudah dilaksanakan secara efektif. Berdasarkan fakta yang didapat pada penelitian yang dilakukan oleh penulis, sebagian besar isi dari Resolusi Dewan Keamanan PBB Nomor 2328 sudah dilaksanakan oleh para pihak yang ditujukan dalam isi Resolusi tersebut, hanya poin ke delapan yang belum terpenuhi. Menurut penulis, untuk mengatakan suatu Resolusi telah dilaksanakan secara efektif atau tidak, kita tidak harus menitikberatkan pada

\footnotetext{
111) https://news.detik.com/internasional/d3378767/evakuasi-di-aleppo-telah-tuntas,
}

Teddy Nurcahyawan \& Lauw Wisnu Efektivitas Sanksi Dewan Keamanan Perserikatan Bangsa-bangsa...

kesempurnaannya, tetapi pada upaya yang telah dilakukan untuk melaksanakan amanat yang terdapat pada Resolusi tersebut.

\section{DAFTAR PUSTAKA}

\section{A. Buku}

Ashidiqqie, Jimly dan M Ali Safa'at, Teori Hans Kelsen Tentang Hukum, cet kedua, (Jakarta: Konstitusi Press, 2012).

Adolf, Huala. Aspek-Aspek negara dalam hukum internasional, cetakan ketiga. (Jakarta: RajaGrafindo Persada, 2002).

Arief, Barda N, Kapita Selekta Hukum Pidana, cet Ketiga, (Bandung: Citra Aditya Bandung, 2013).

Baylis, John dan Steve Smith, The Globalization of the World Politics, (Oxford: Oxford University Press, 1997).

Bowett, D.W., Hukum Organisasi Internasional, diterjemahkan oleh Bambang Iriana Djajaatmadja, S.H., (Jakarta: Sinar Grafika, 1995).

Brierly,J.L. Hukum Bangsa-

Diakses pada tanggal 30 Juni 2017, Pukul 14:42 WIB. 


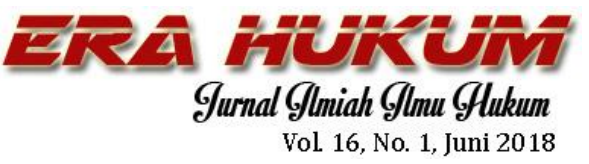

Bangsa, diterjemahkan oleh

Moh. Radjab, (Jakarta: Bhratara, 1963).

H, S. Salim, dan Eris Septiana Nurbani, Penerapan Teori Hukum Pada Tesis dan Disertasi, Edisi Pertama, cet Kesatu, (Jakarta: Rajawali Press, 2013).

Istanto, F Sugeng, Hukum Internasional, (Yogyakarta: Atmajaya Yogyakarta, 1998).

Kuncahyono, Trias. Musim Semi di Suriah, Anak-anak Sekolah Penyulut Revolusi, (Jakarta: Kompas, 2013).

Kusumaatmadja, Pengantar Hukum Internasional, Alumni, Bandung, 2015.

Lesch David W. Syria, The Fall of the House of Assad, (USA: Yale University Press, 2012).

Marzuki, Peter Mahmud. Penelitian hukum, (Jakarta: Kencana Premata Media, 2006).

Mauna, Boer. Hukum Internasional, Pengertian Peranan dan Fungsi dalam Era Dinamika Global, Edisi kedua, Cetakan keenam, (Bandung: Alumni, 2015).

Schermers, Henry G. dan Niels M. Blokker. International Institutional Law: Unity
Teddy Nurcahyawan \& Lauw Wisnu Efektivitas Sanksi Dewan Keamanan Perserikatan Bangsa-bangsa...

Within Diversity, Fifth Revision Edition, Martinus Nijhoff, Boston, 2011).

Shaw, Malcolm N. QC. Hukum Internasional, diterjemahkan oleh Derta Sri Widowatie, Imam Baehaqi dan $M$. Khozim, (Bandung: Nusamedi, 2013).

Soekanto, Soerjono, Efektivitas Hukum dan Peranan Saksi, (Bandung: Remaja Karya, 1985).

Mamudji, Penelitian Hukum Normatif, Suatu Tinjauan Singkat, (Jakarta: Rajagrafindo Perkasa, 2006).

Suatu Pengantar diterjemahkan oleh Bambang Iriana Djajaatmadja, S.H., (Bandung: Rajawali Pers, 1996).

Starke, J.G. Pengantar Hukum Internasional, Edisi Kesepuluh, Jilid 1, diterjemahkan oleh Bambang Iriana Djajaatmadja, S.H., (Jakarta: Sinar Grafika, 2010).

Pengantar Hukum Internasional, diterjemahkan oleh Bambang Iriana Djajaatmadja, S.H., Edisi Kesepuluh, Jilid 2, (Jakarta: Sinar Grafika, 2010). 


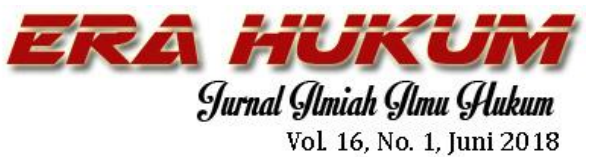

Suwardi, Sri S. Penyelesaian Sengketa Internasional, (Jakarta: Universitas Indonesia, 2006).

Suryokusumo, Sumaryo, Organisasi Internasional, (Jakarta: UI Press, 1987).

Tamburaka, Apriadi, Revolusi Timur Tengah, Kejatuhan Para Penguasa Otoriter di Negara-negara Timur Tengah, (Jakarta: Narasi, 2011).

Van Hoof, G.H.J. Rethinking the Sources of International Law, diterjemahkan oleh Hatta, Pemikiran Kembali SumberSumber Hukum Internasional, Yayasan Hak Asasi Manusia, Demokrasi, dan Supremasi Hukum, (Bandung: Alumni, 2000).

\section{B. Regulasi}

Indonesia. Piagam Perserikatan

Bangsa-Bangsa.

Fakultas Hukum Universitas Tarumanagara, Peraturan Dekan Fakultas Hukum Universitas Tarumanagara Nomor: 23 PD/FH/UNTAR/III/2014

Tentang Skripsi. (Jakarta: FH UNTAR, 2014).

Perserikatan Bangsa-Bangsa. UN

Security Council Resolution
Teddy Nurcahyawan \& Lauw Wisnu Efektivitas Sanksi Dewan Keamanan Perserikatan Bangsa-bangsa...

2328 (2016).

\section{Internet}

Dewan Keamanan Perserikatan Bangsa-Bangsa. "UN Security Council 2328" https://www.un.org/en/ga/sear ch/view_doc.asp?symbol=S/R ES/2328(2016), 27 April 2017.

Anonim. "Pengertian Studi Kepustakaan”,

https://www.scribd.com/ doc/57297015/Pengertianstudi-kepustakaan. 29 Januari 2017.

Anonim. "Syria's Assad Appoints New Prime Minister", http://www.dw.com/en/syriasassad-appoints-new-primeminister/a-19348233, 16 Mei 2017.

Anonim. "Sekilas Mengenai Negara Suriah (Syria) dan Jumlah Penduduknya", http://www.muslimedianews.c om/2014/03/sekilas-mengenalnegara-suriah-syria.html, 16 Mei 2017.

Anonim. "Mesir dan Arab Menjadi satu dalam Republik Persatuan Arab”, https://tirto.id/mesirdan-suriah-menjadi-satudalam-republik-persatuanarab-cjxe, 12 Juli 2017.

Anonim, "Ramadhan Koalisi Negara Arab Menyerang Israel (Perang Yom Kippur)", 


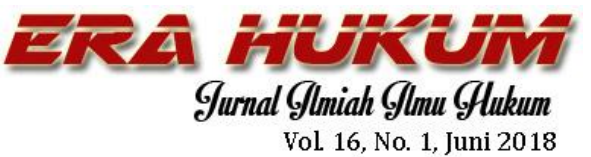

http://kisahmuslim.com/592710-ramadhan-koalisi-negaraarab-menyerang-israel.html, 12 Juli 2017.

Anonim. "Pengertian Wawancara dan Jenis-Jenis wawancara", http://www.

pengertianpakar.com/2015/06/

pengertian-wawancara-danjenis-jenis-wawancara.html", 29 Januari 2017.

Anonim. "Pengertian Efektivitas Kerja Menurut Definisi Para Ahli", http://www.landasanteori.com/ 2015/10/pengertianefektivitas-kerjaada lah.html, 24 April 2017.

Anonim. "UNSC Adopts Resolution 2328 Regarding Monitoring of Aleppo Evacuation", http://syriainstitute.org/calend ar/unsc-adopts-resolutions2328-2016-regar dingmonitoring-of-aleppoevacuation/, 19 April 2017.

Anonim. "Syria: The Stoey of the Conflict",

http://www.bbc.com/news/ world-middle-east-26116868, 23 April 2017.

Anonim. "Syria: Humanitarian situation Catastrophic", https://www. icrc.org/en, 3 Januari 2017.

Anonim. DK PBB Rilis Resolusi
Teddy Nurcahyawan \& Lauw Wisnu Efektivitas Sanksi Dewan Keamanan Perserikatan Bangsa-bangsa...

Tentang Transisi Politik di Suriah, http://www.bbc.com/indonesia /dunia/2015/12/151218_dunia _dkpbb_resolusi_suriah, 28 Juni 2017.

Anonim. "UNSC Adopts Resolutions $2328 \quad 2016$ Regarding Monitoring of Aleppo Evacuation", 28 Juni 2017.

Anonim. "Health Care in Syria Before and During the Crisis", https://www.ncbi.nlm.nih.gov/ pmc/articles/PMC3697421/\#re f7, 30 Juni 2017.

Anonim. "Syria: Humanitarian Situation and ICRC/Red Crescent Response, March 2012",

https://www.icrc.org/eng/reso urces/documents/overview/ syria-update-25-02-2012.htm, 30 Juni 2017.

Anonim. "Even Wars Have Limits: Health Care Workers and Facilities Must be Protected", https://www.icrc.org/en/docu ment/hcid-statement, 30 Juni 2017.

Anonim. "Allepo Hospital Attacked During Ceasefire", https://defendmedicalimp artiality.org/? $\mathrm{p}=1868,8$ Juli 2017.

Aritonang, Margareth S. "Indonesia's Aid Groups 


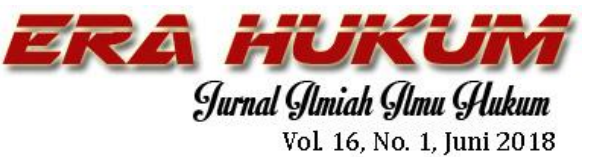

Respond to Humanitarian

Crisis in Aleppo",

http://www.thejakartapost.com

/news/2016/12/20/ indonesias-

aid-groups-respond-to-

humanitarian-crisis-in-

aleppo.html, 30 Juni 2017

Muhaimin. 10 Jawaban Assad soal

Perang Suriah, ISIS, hingga

Propaganda Barat,

http://international.sindonews. com/read/1046458/43/10-

jawaban-assad-soal-perang-

suriah-isis-hingga-

propaganda-barat-

1442655821, 19 September 2015.

Nugroho, Bagus P. "Evakuasi di Aleppo Telah Tuntas, https://news.detik.com/interna sional/d-3378767/evakuasi-dialeppo-telah-tuntas, 30 Juni 2017.

русский, "PHR Urges Russian Medical Community to Protect Health in Syria", http://physiciansforhumanright s.org/library/phr-urgesrussian-medical-communityto-protect-health-in-syria.html, $\underline{30 \text { Juni } 2017}$

\section{Makalah}

Maulana, Alfian. "Konflik Suriah", Makalah (Jakarta: Universitas Muhammadiyah, 2012).

\section{E. Artikel atau Jurnal}

Teddy Nurcahyawan \& Lauw Wisnu Efektivitas Sanksi Dewan Keamanan Perserikatan Bangsa-bangsa...

Archibugi, Daniel. Italian National Research dan London School of economic and Social Sciences, Cosmopolitan Guidelines for Humanitarian Intervention, (Alternatives, Global, Local, Political, Vol . 29, No . 1, Spring 2004, pp 121), Jurnal (Rome, 2003).

Barros, James. The League of Nations and The Great Powers, Jurnal (Bulgary: The Greek, Bulgarian Incident,1970).

Blanchard, Christopher. Dkk. Armed Conflict in Syria: Overview and U.S. Response, Congressional Research Service, edisi 9 Oktober 2015, Jurnal, (Congressional Research Service, 2015).

de Groof, Melanie. Arms Transfers to the Syrian Arab Republic: Practice and Legality, Les Rapports du Grip, edisi September 2013, Jurnal, (Groupe de Recherche ed d'Information Sur la Paix et la Securitie (GRIP), 2013).

Hoff, Frederick C. and Alex Simon, Sectarian Violence in Syria's Civil War: Causes, Consequences, and Recommendations and mitigations, Edisi Maret 2013, Jurnal, (USA: The Center for the Prevention of Genocide: United States Holocaust Memorial Museum, 2013). 


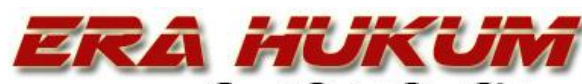

Gurnal Glmiah Glmu Glukum

Vol 16, No. 1, Juni 2018

Dias, Clerence J, Research on Legal Service and Poverty: its Relevance to the Design of Legal Service Program in Developing Countries, Wash, Jurnal, (U.L., 1975).

Seidman Robert B. Law Order and Power, (Massachusetts: Adition Publishing Company Wesley Reading Massachusetts, 1972).

Spedaonthel, Krisis Suriah: AS, Inggris, Israel, Uni Eropa VS Rusia (Krisis Suriah Part-1), Artikel, 2013

Taghrid, Mohammad. "Syrian Arab Republic_", Report, (Humanitarian Needs Overview, edisi JanuariOktober 2016, UNRWA), 2016.

Tobing, Raida L. dkk. Efektivitas Undang-Undang Money Laundering, Jurnal, (Jakarta: Badan Pembinaan Hukum Nasional, Kementrian Hukum dan HAM RI,, 2011).

Türkmen, Füsun. Cyprus 1974 Revisited: Was It Humanitarian Intervention?, Artikel, (Perceptions, Galatasaray University, 2005).

\section{F. Kamus}

Martin Basiang, Law Dictionary, Second Edition, (Jakarta:
Teddy Nurcahyawan \& Lauw Wisnu Efektivitas Sanksi Dewan Keamanan Perserikatan Bangsa-bangsa...

Gramedia Pustaka Utama, 2016).

Garner, Bryan A. ed., Black's Law Dictionary, Seventh Edition, Book 1, (Minn: West Group, ST. Paul, 1999).

John M. Echols dan Hassan Sadily, An English-Indonesian Dictionary, (Jakarta: Gramedia Pustaka Utama, 2010).

Gamal Komandoko, Ensiklopedia Pelajar dan Umum, (Jakarta: Pustaka Widyatama, 2010). 